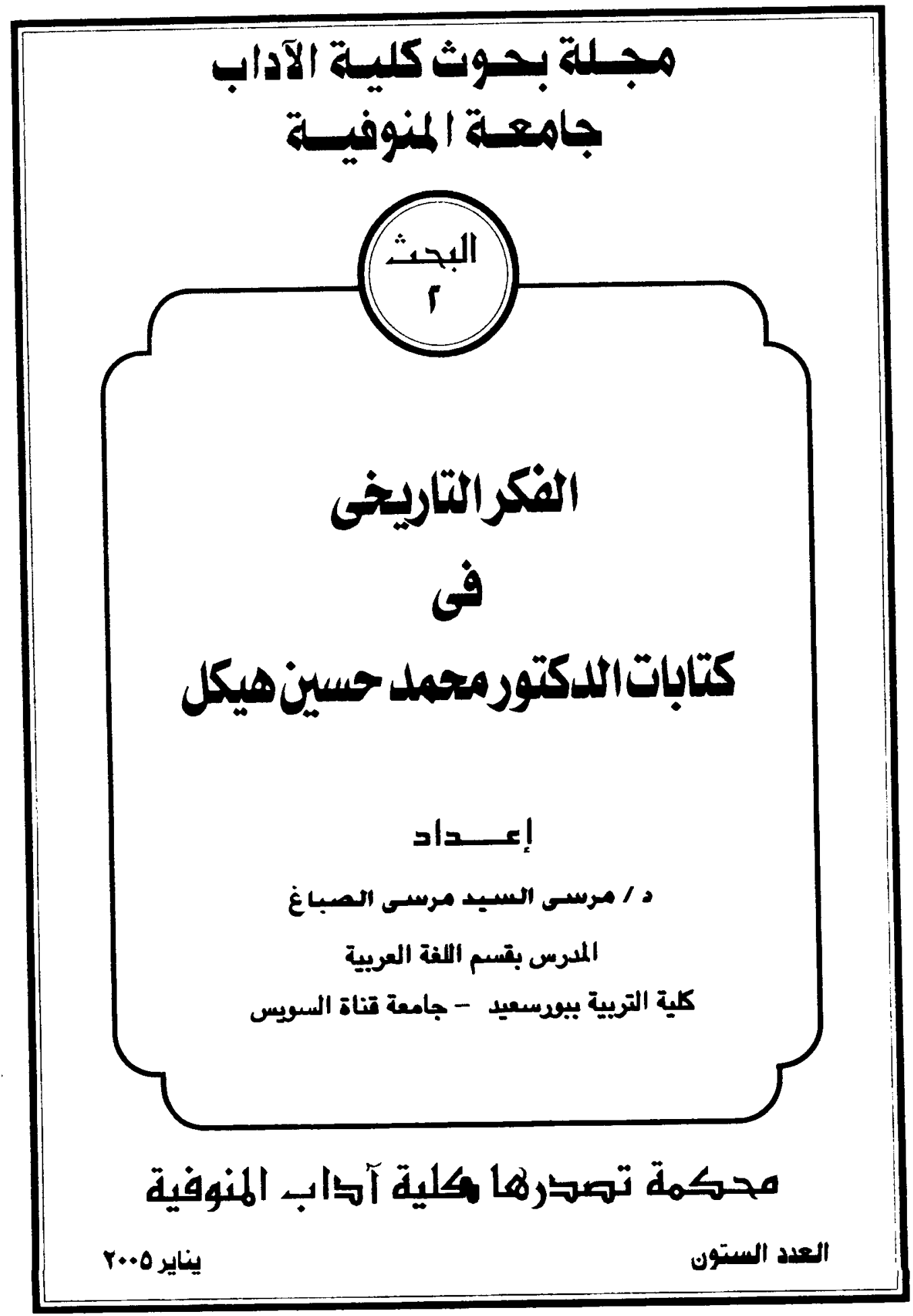




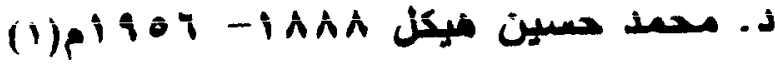

ذلك الرجل الذي عاش حياة ملينة بالاعاجيب حانلة بالصر اعات السباسبة والاهتعاعية

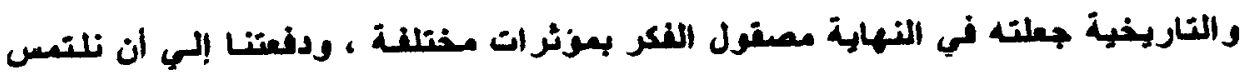

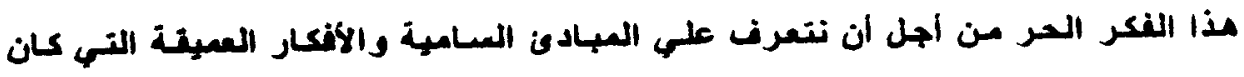

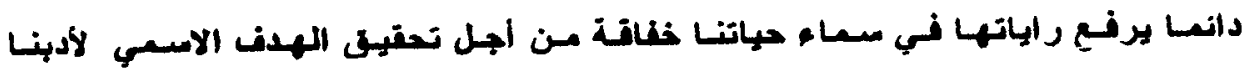
العربه وتر الثنا الإسلامب .

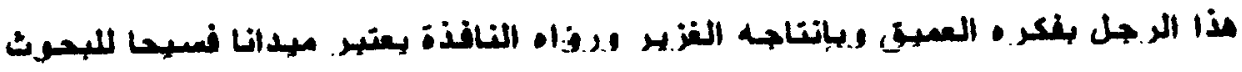

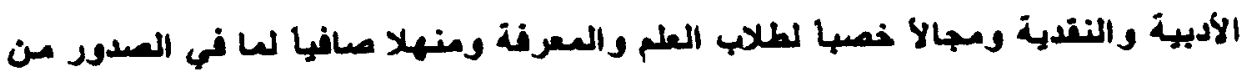

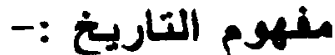

بعتبر كل إنعسان إلـي هد مسا مغزخا بحتفط في ذاكرته بطر انف من الذكريات العسارة

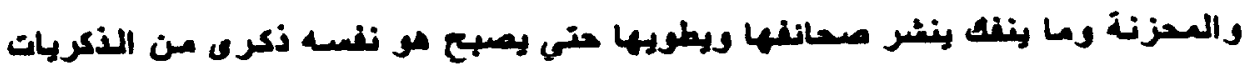

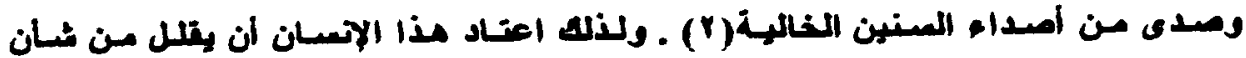

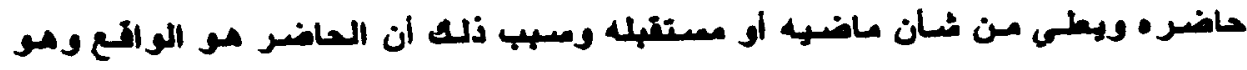

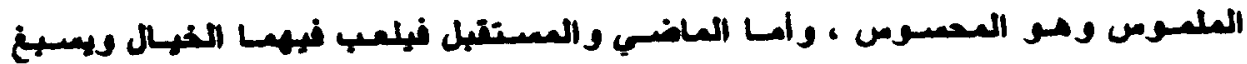

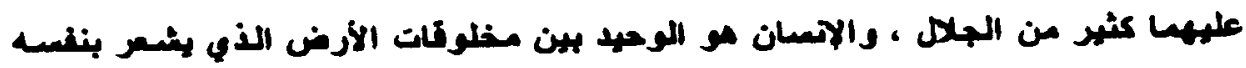

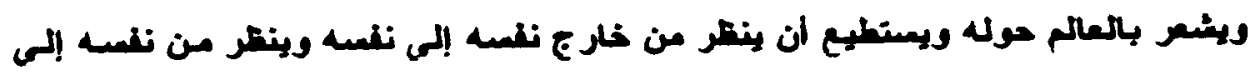

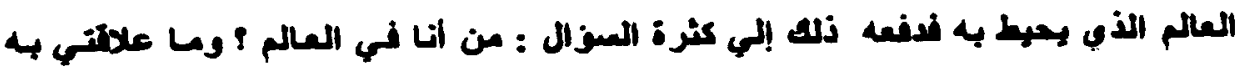

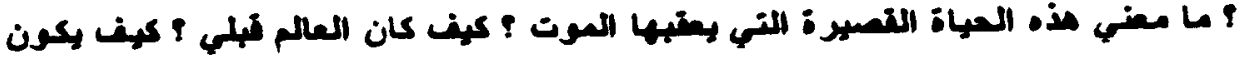

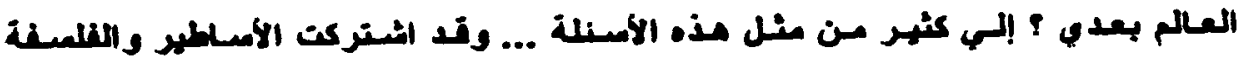

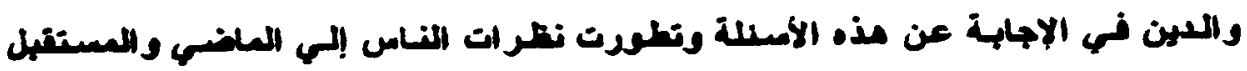

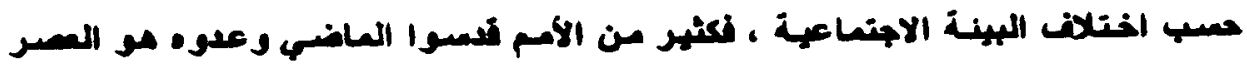

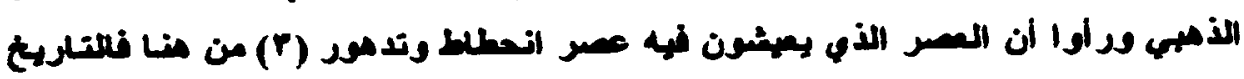

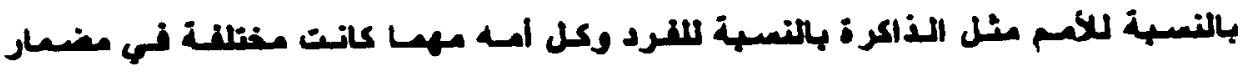




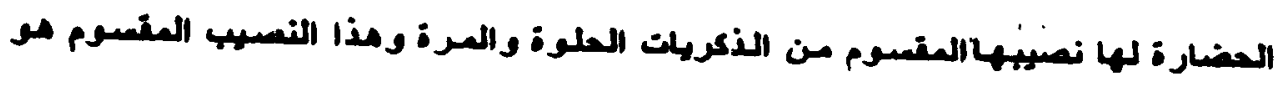

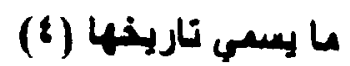

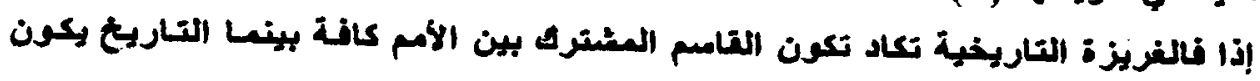

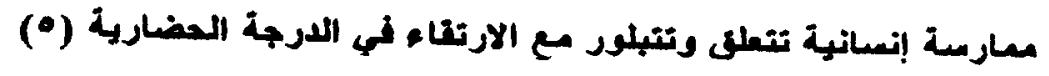
موضوع النارئ : مون

من خلال ما سبى نستطبع ان نقول ان موضوع التاربغ مو المهتمسع الاتعسانه ومكايته

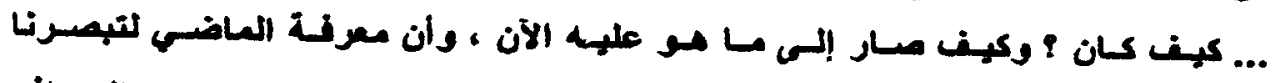

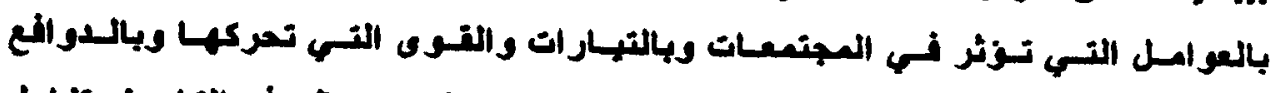

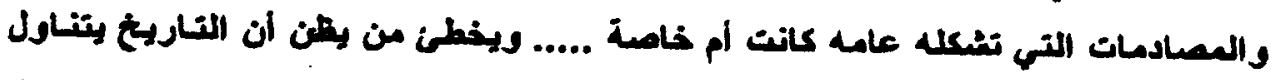

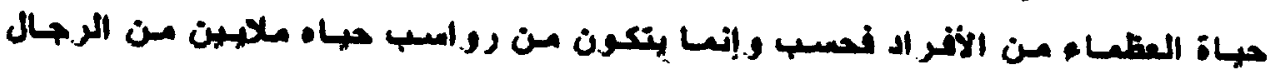

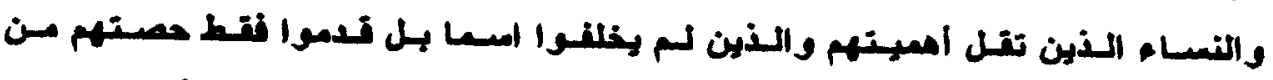

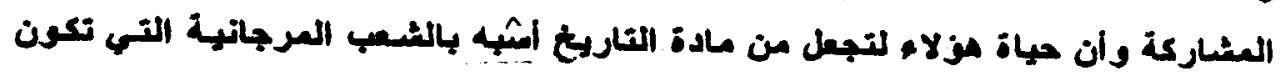

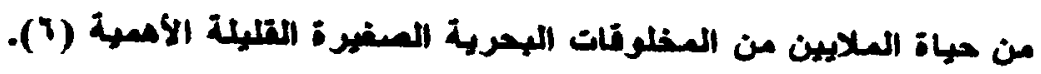

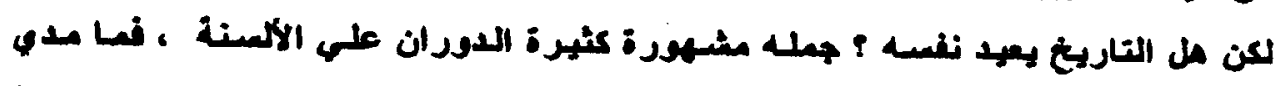

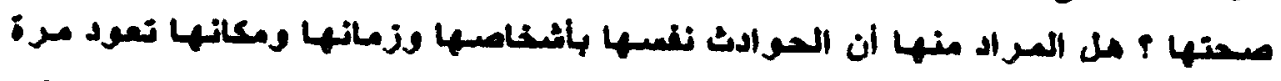

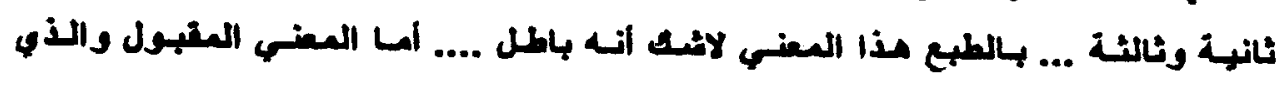

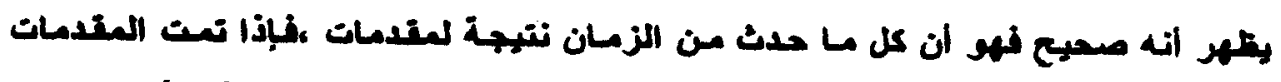

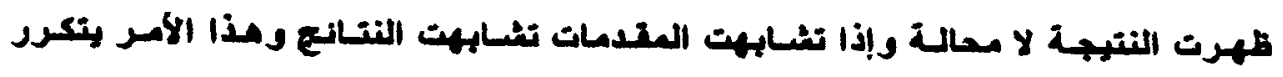

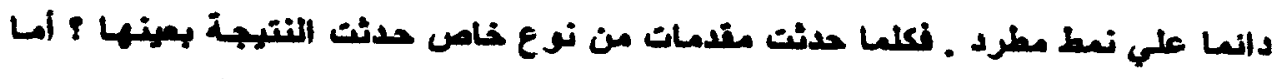

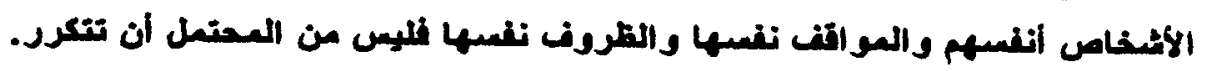
وتاينة التارين :

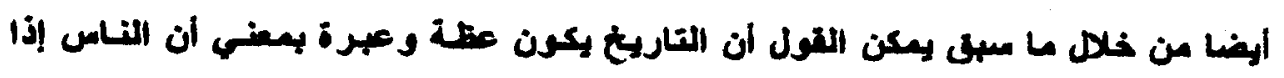

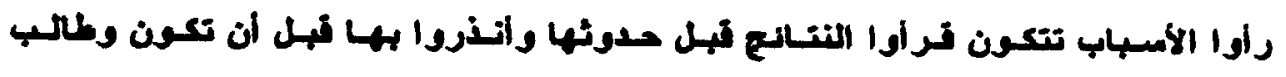

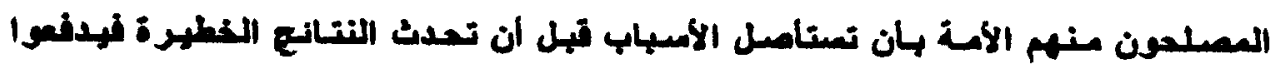

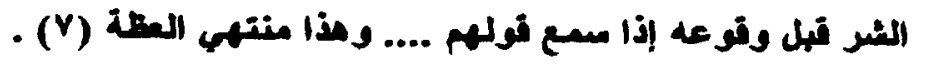




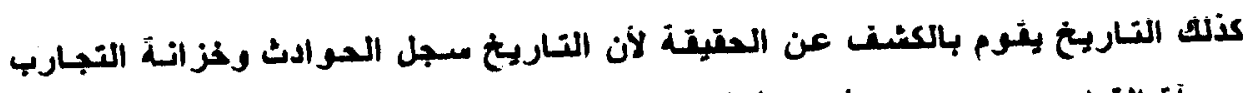

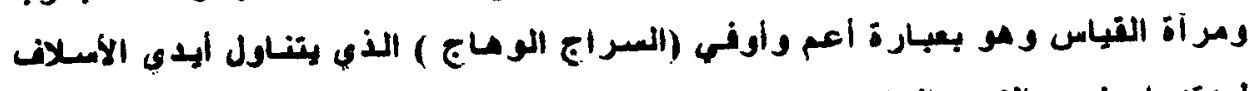

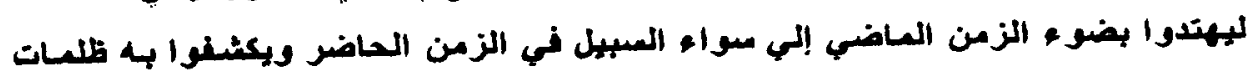

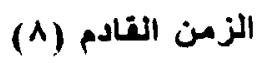

$$
\text { المؤر الملالي وأسلوب كتابه التاريخ : }
$$

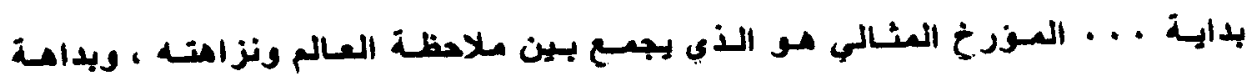

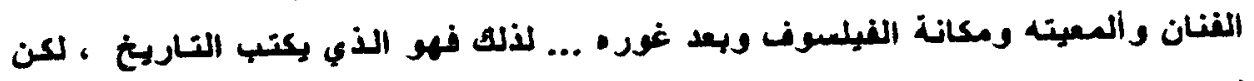

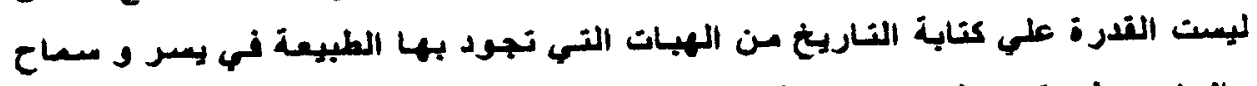

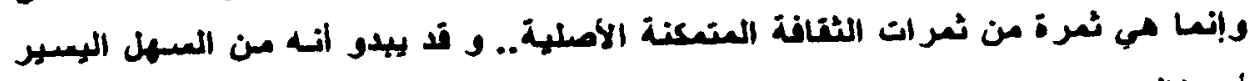

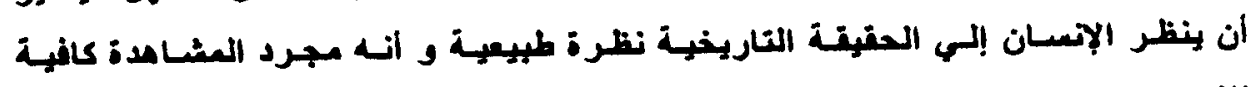

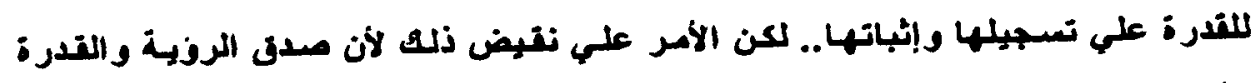

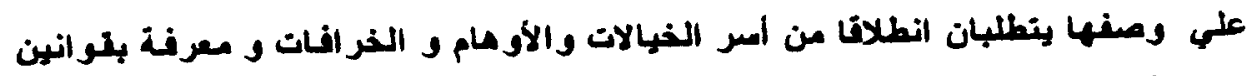

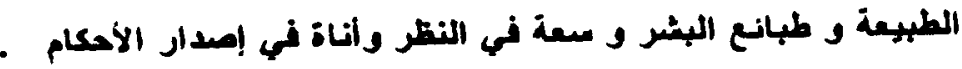

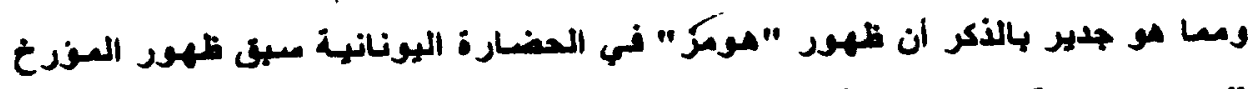

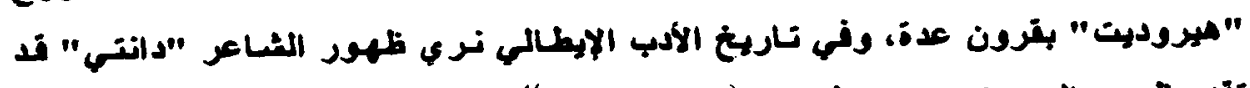

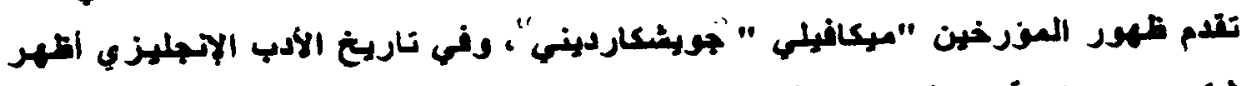

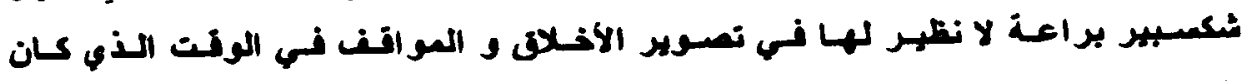

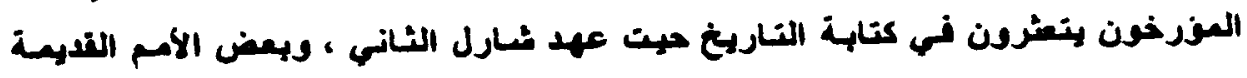

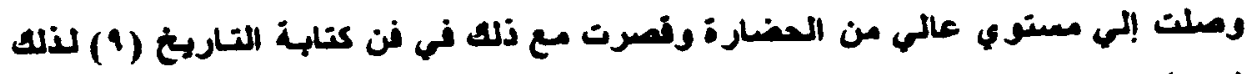

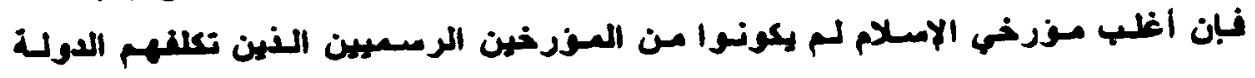

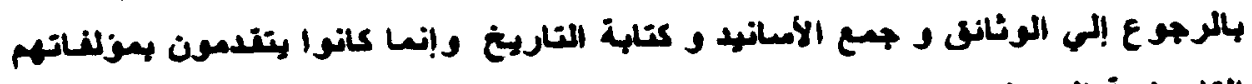

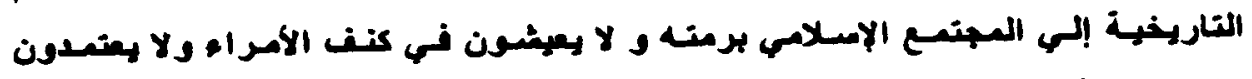

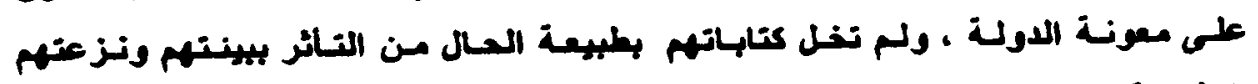

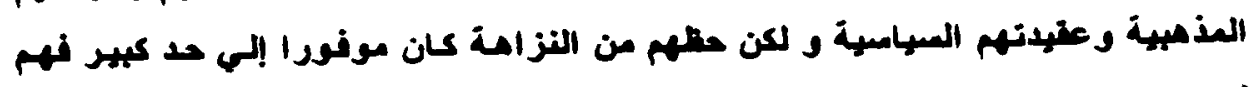

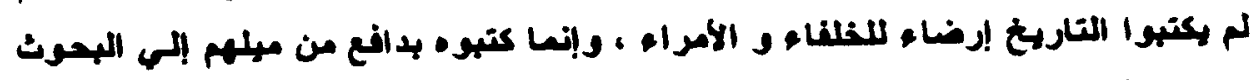
التاربخدة وخمة للمجتمع الاملكمى بوجه عام (1. 
إذا فالعتابة التاربخة فه حاجة إله الموامه المتعدة لان هناك علانة أكهدة بهن الأدب

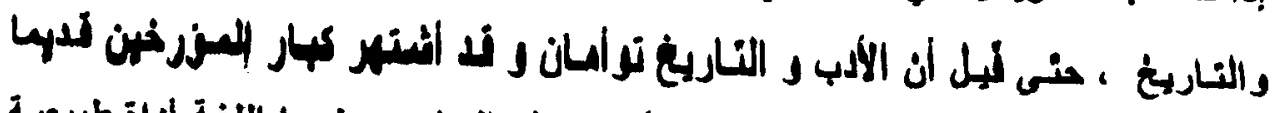

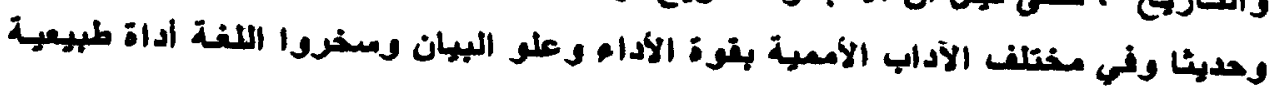

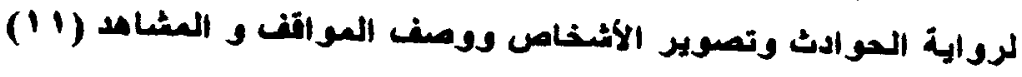

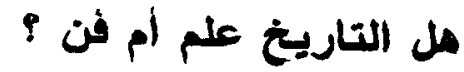

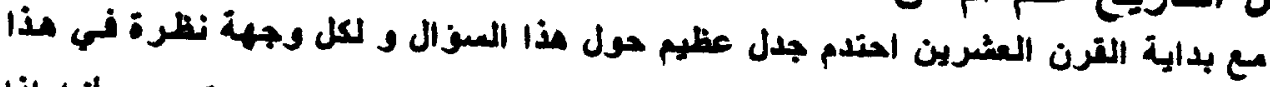

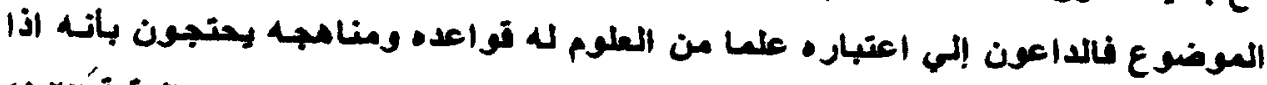

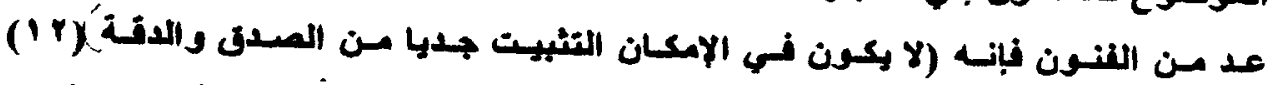

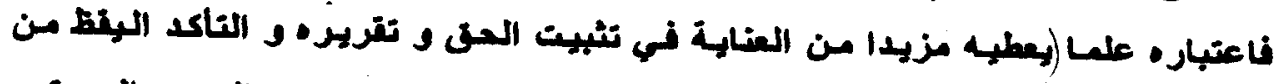

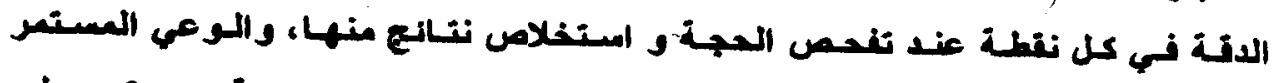

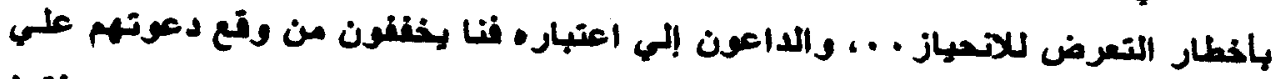

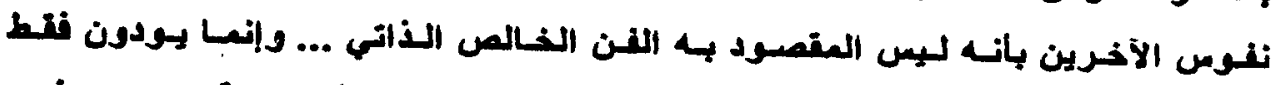

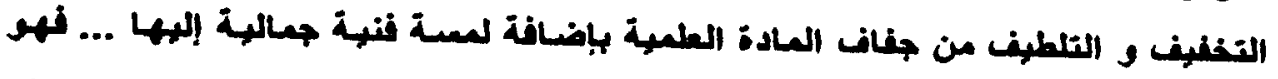

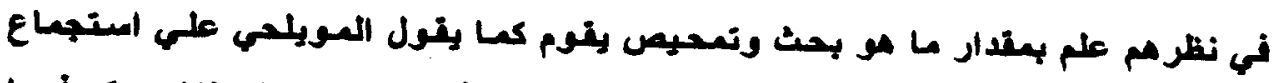

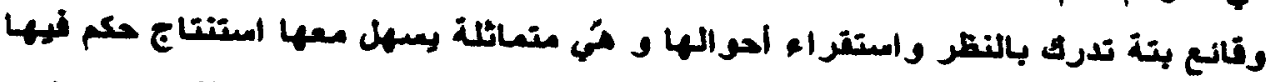

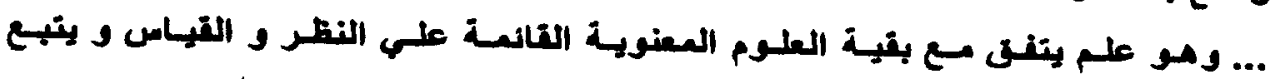

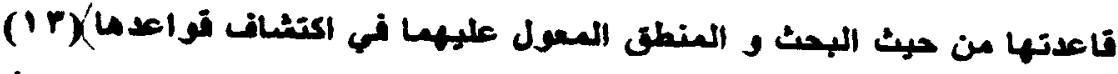

ومن هنا بجب عدم الغلط بهن جانب (العكم د الأداء ) و جانب (الوقائع و الأحداث )

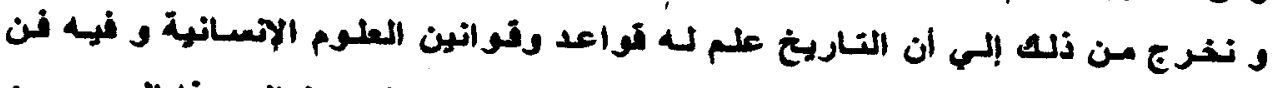

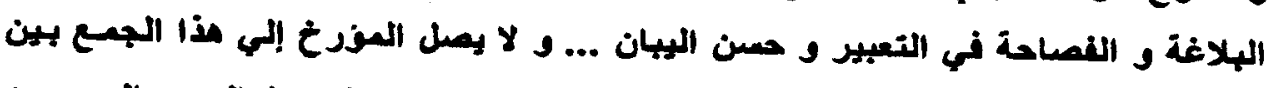

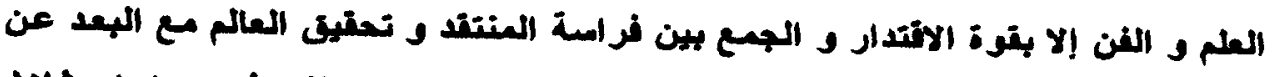

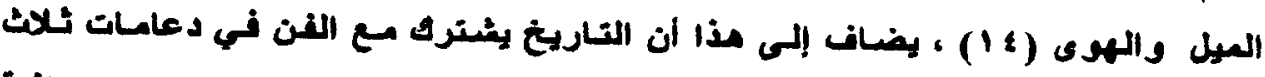

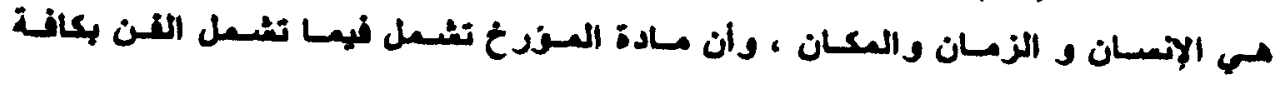

(10) (10) 


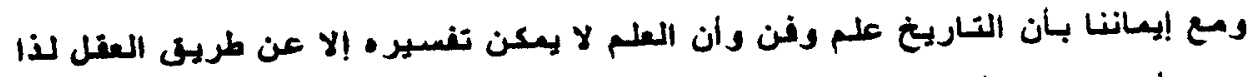

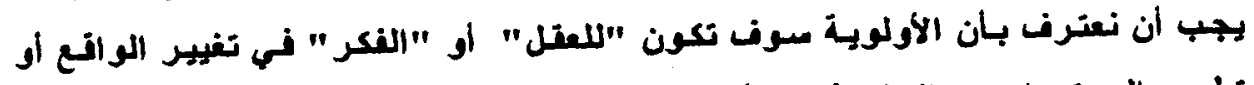

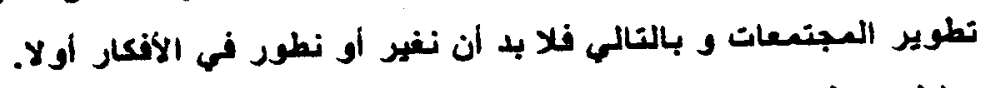

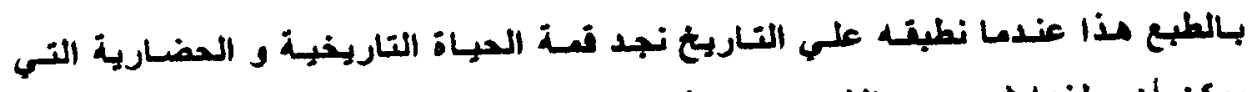

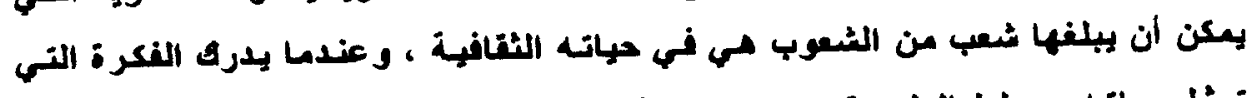

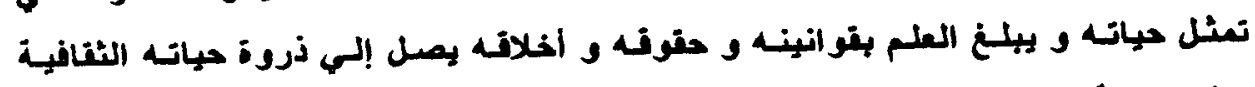

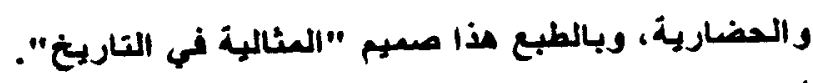

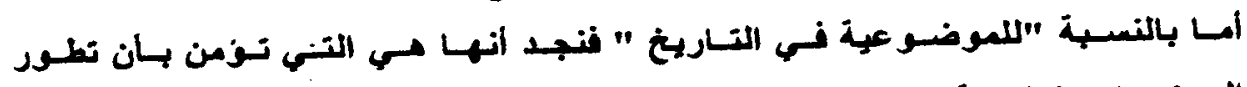

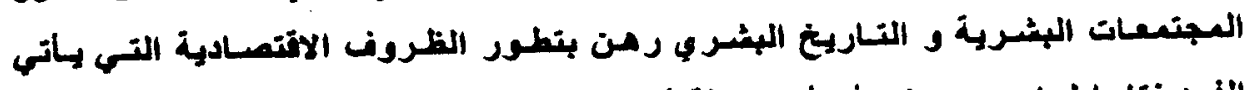

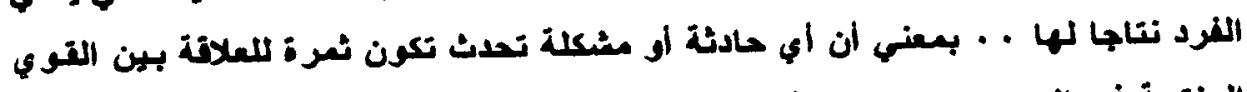

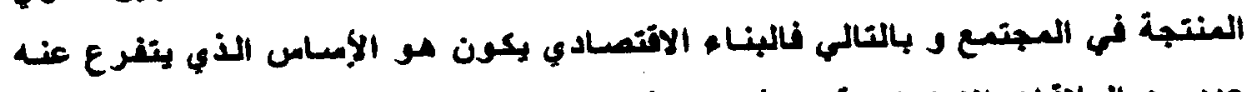

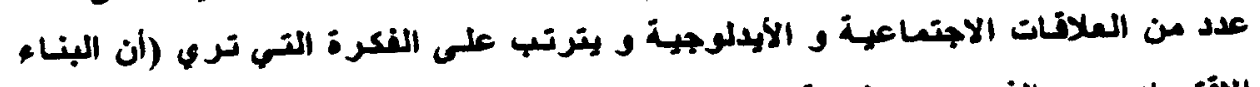

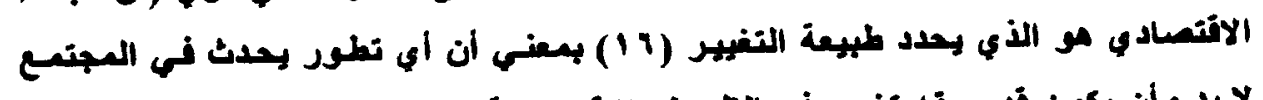

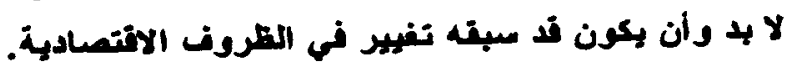

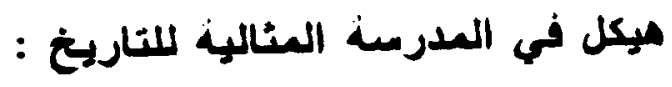

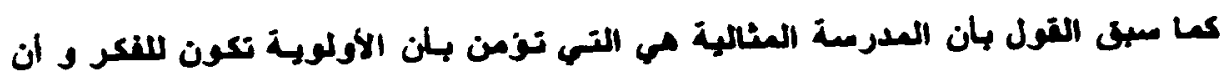

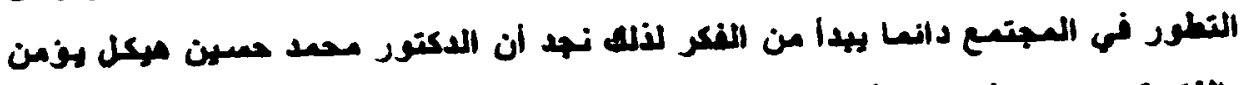

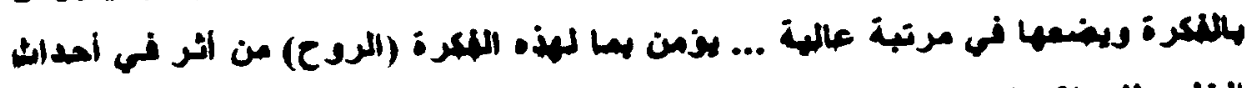

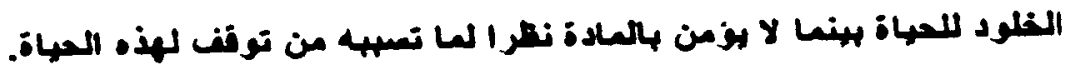

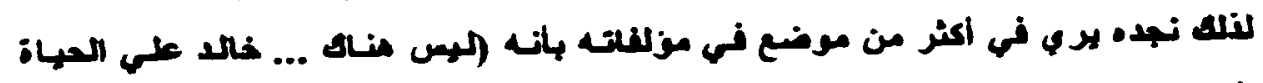

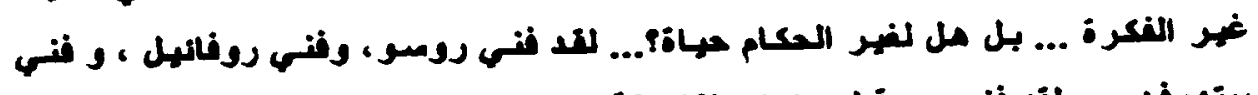

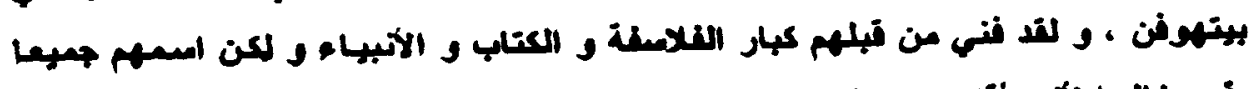

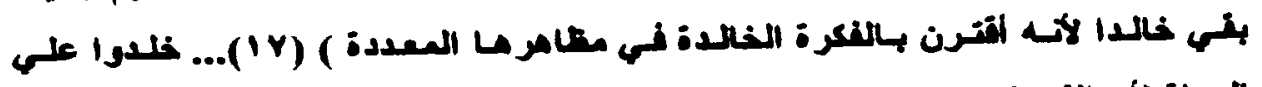

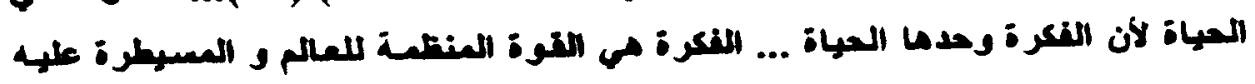




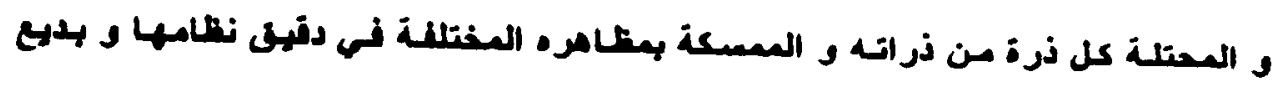

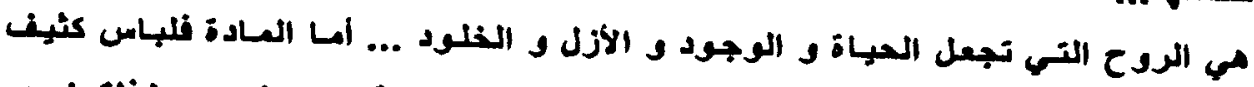
unled

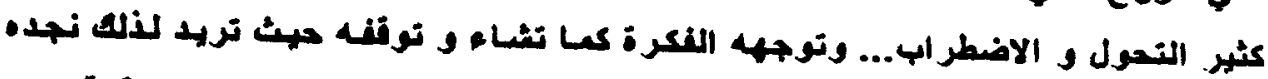

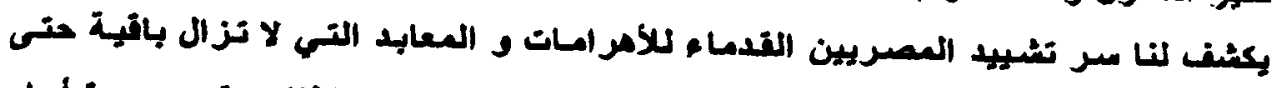

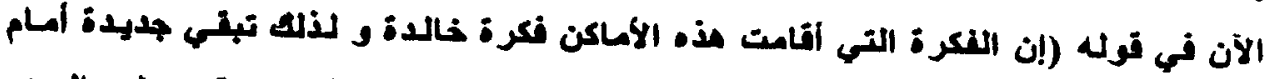

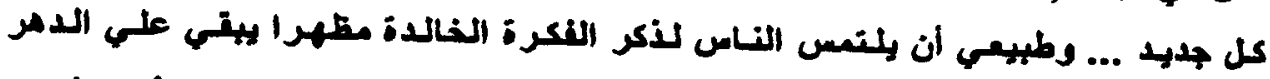

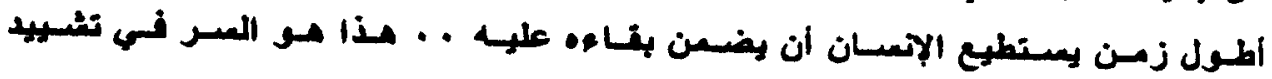

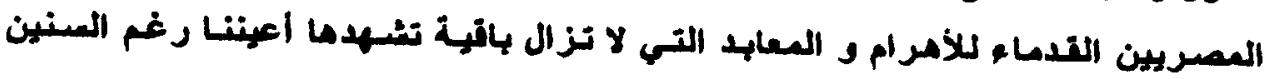

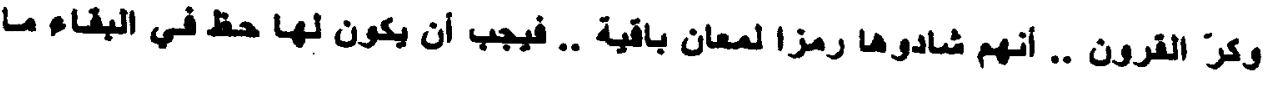

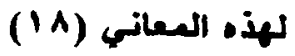

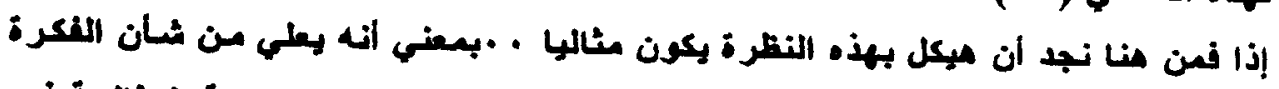

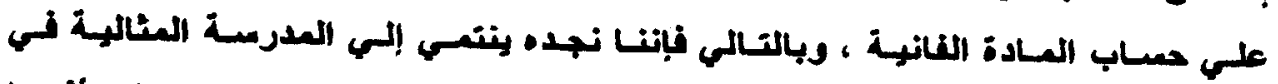

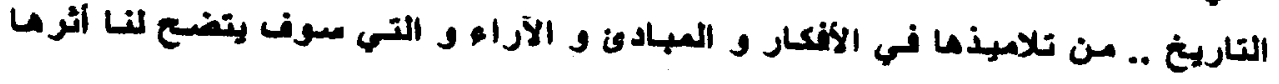

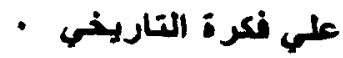

رؤية الدكثور ميكل لمصدر المركة في التاريغ :

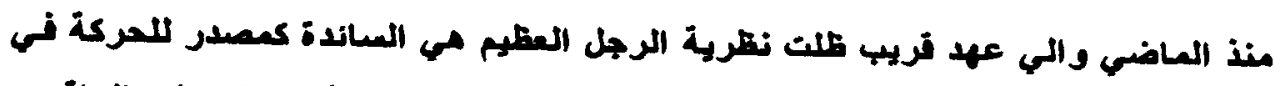

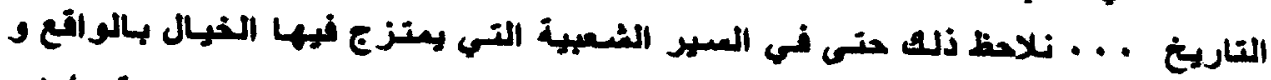

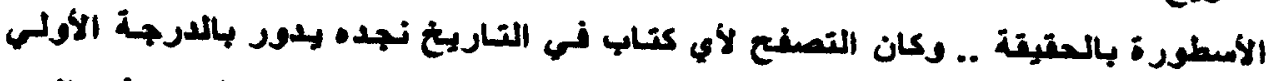

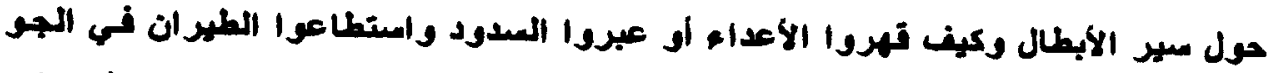

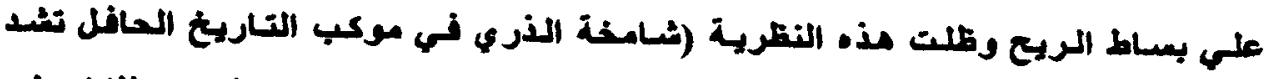

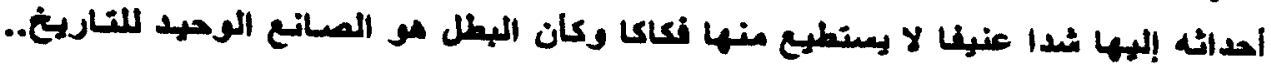

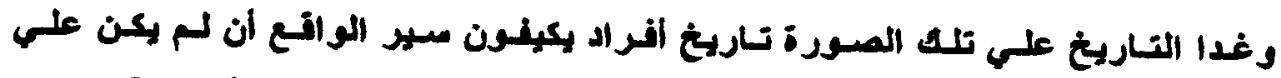

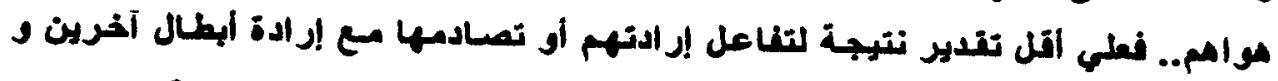

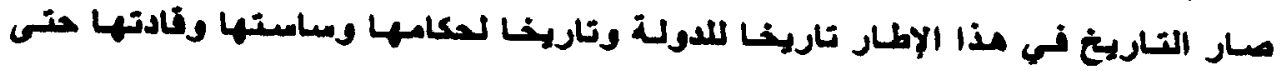

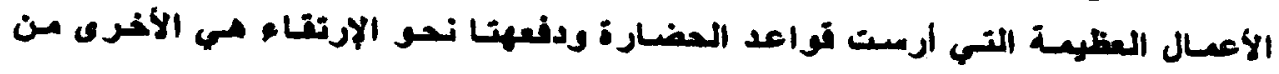

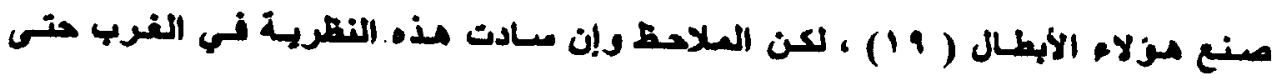




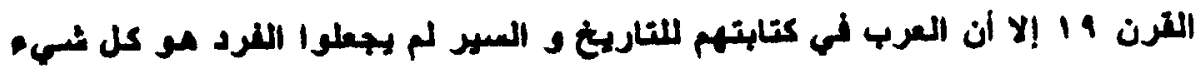

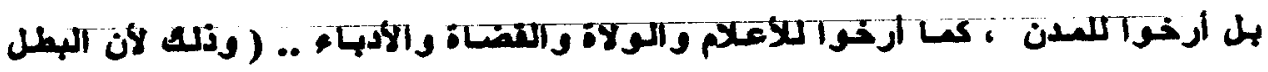

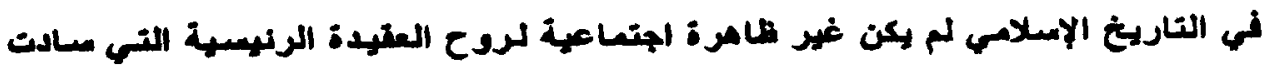

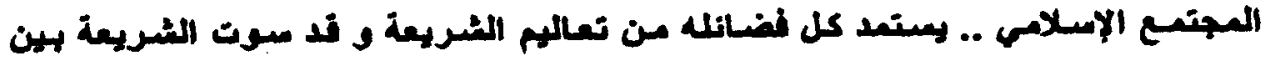

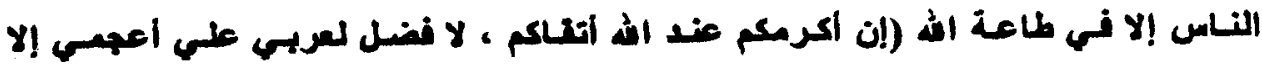

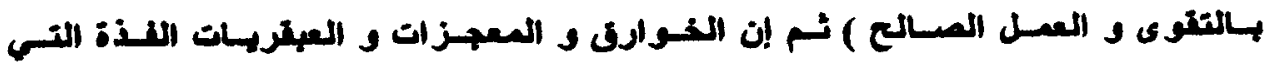

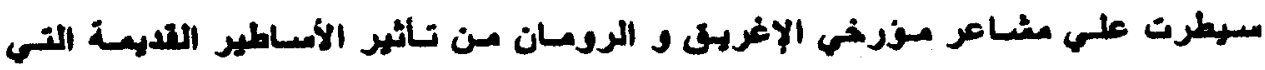

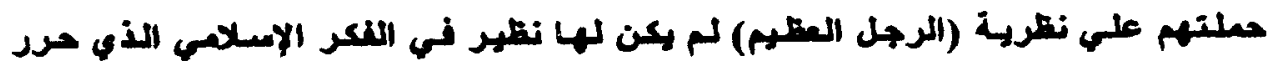

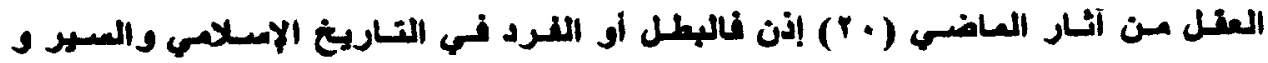

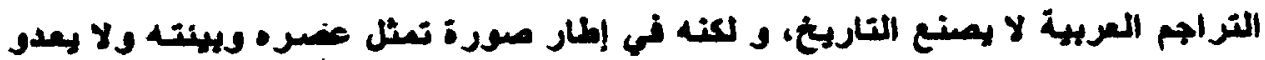

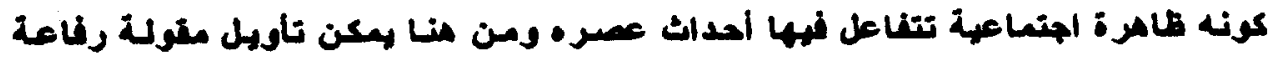

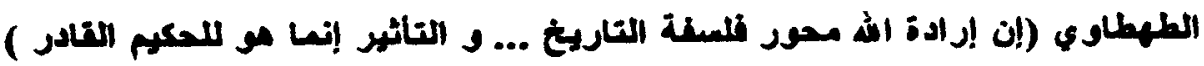

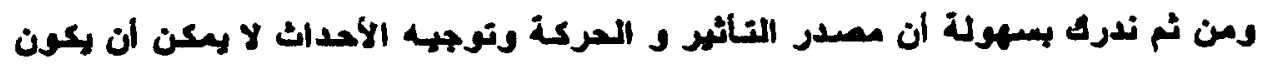

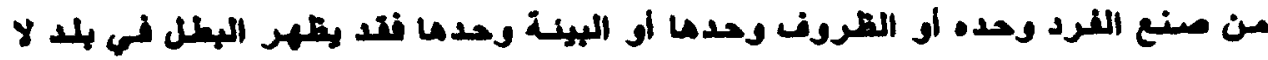

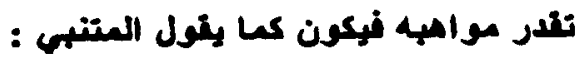

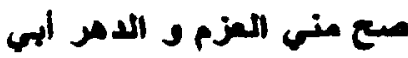

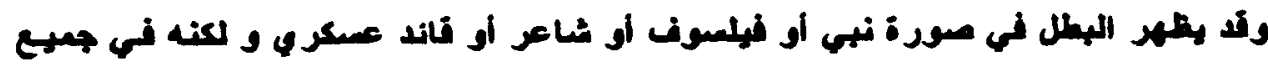

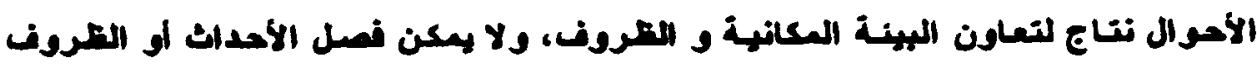

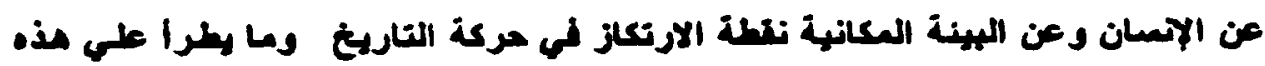

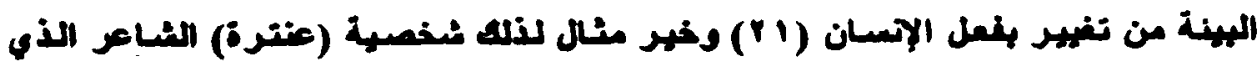

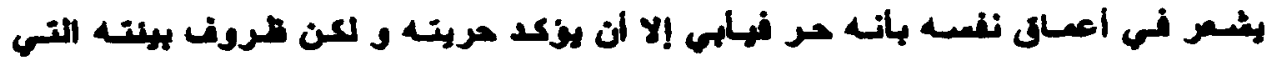

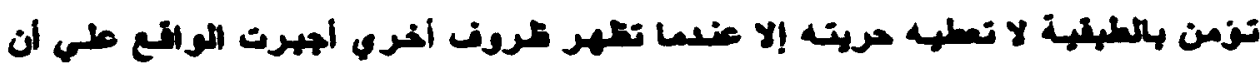

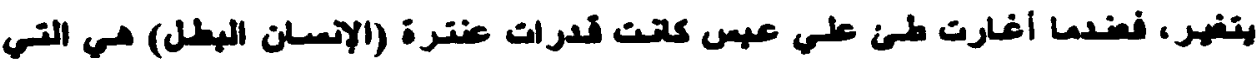

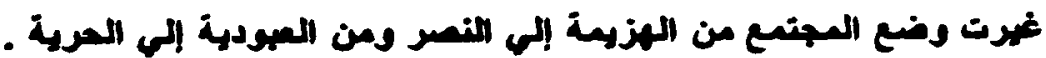

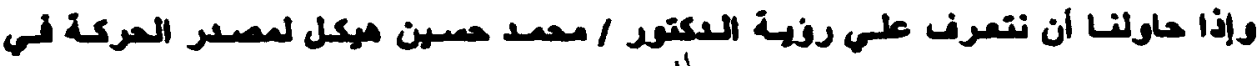

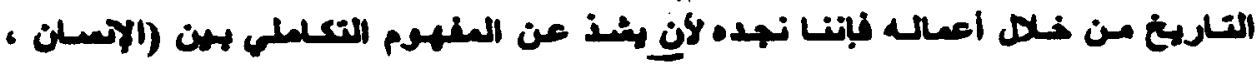

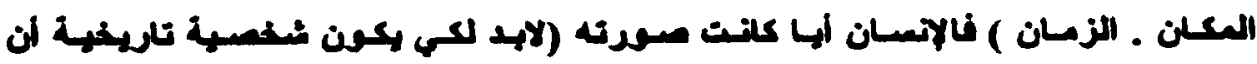

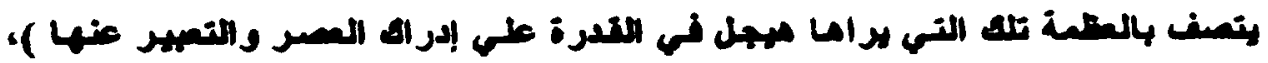




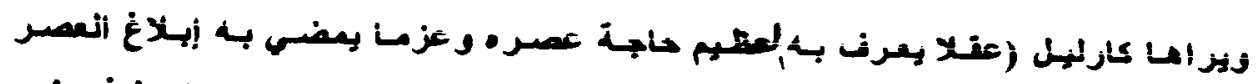

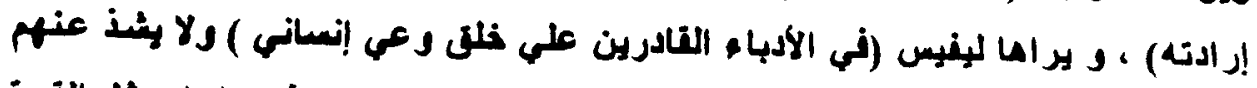

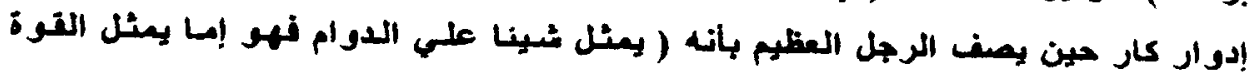

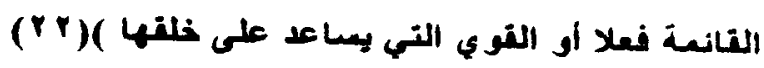

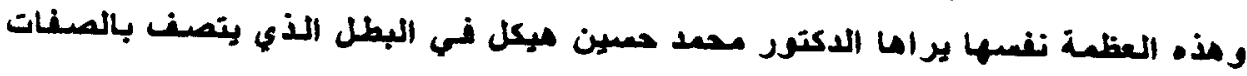
الآتية : ومان

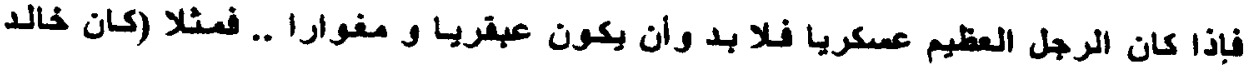

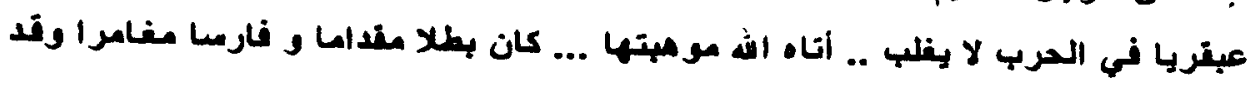

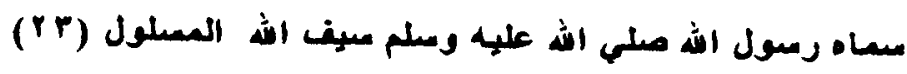

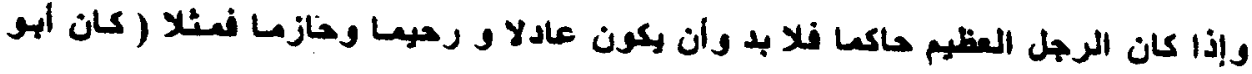

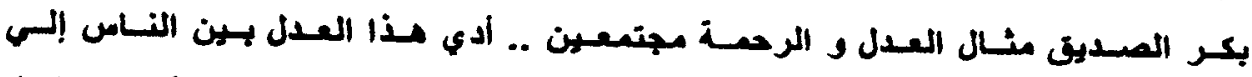

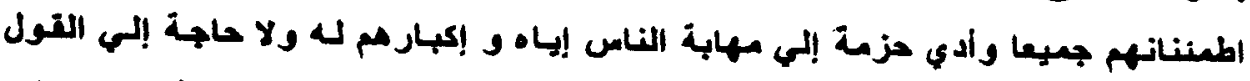

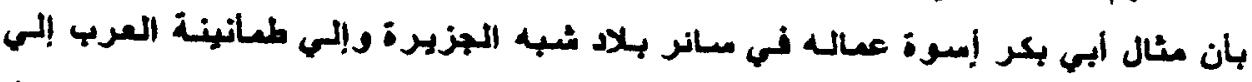

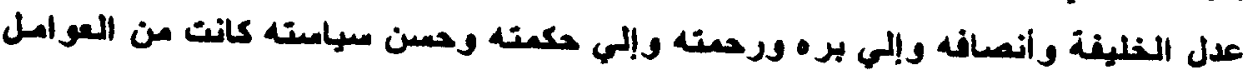

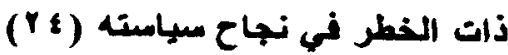

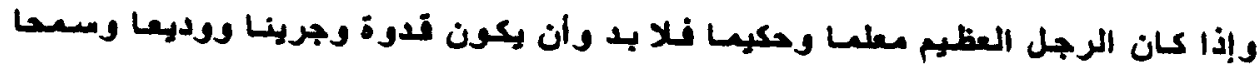

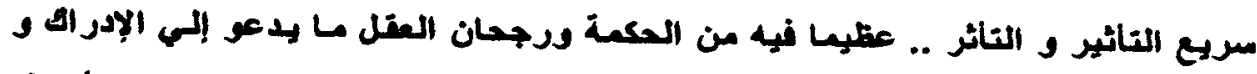

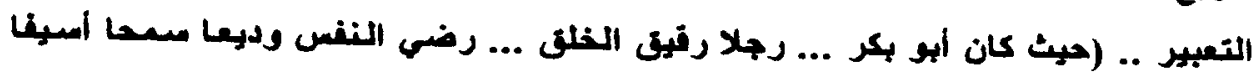

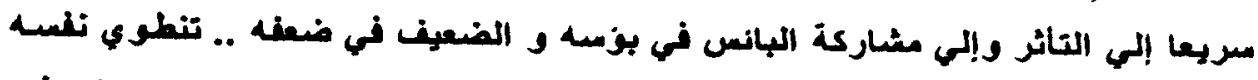

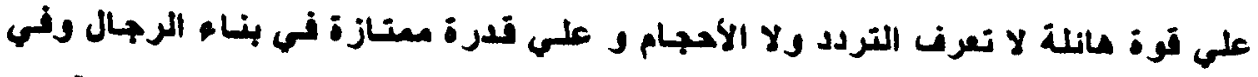

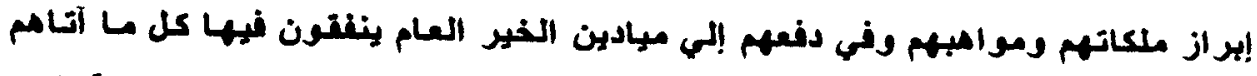

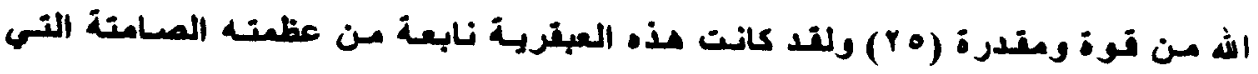

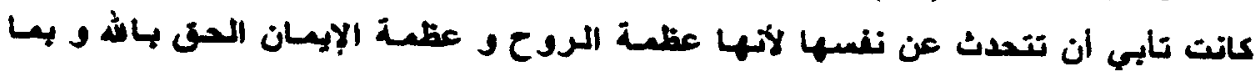

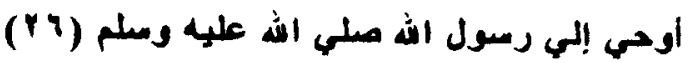

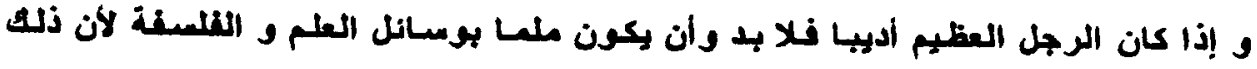

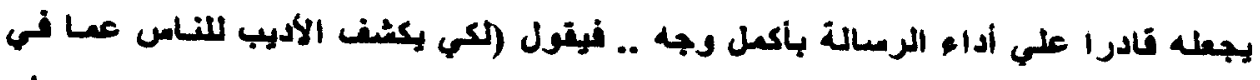

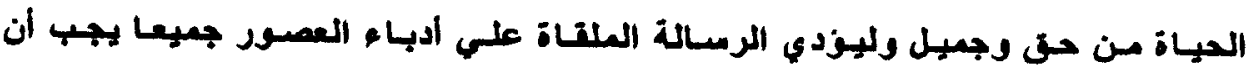




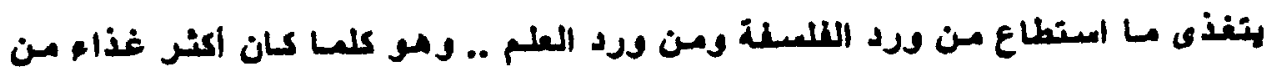

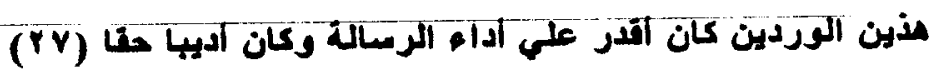

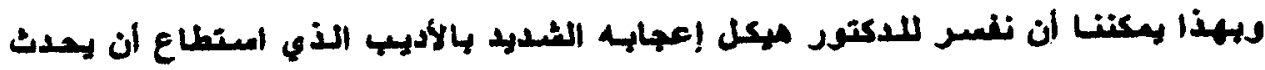

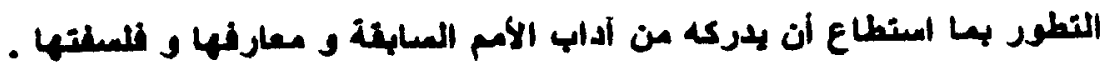

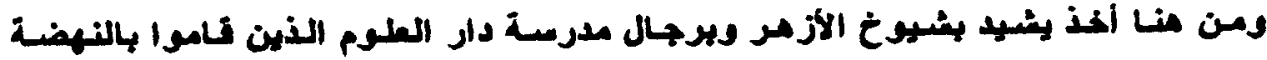

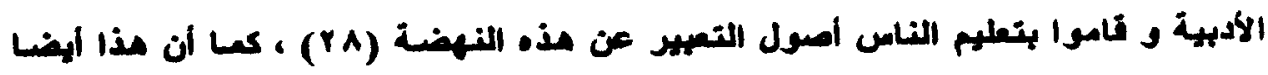

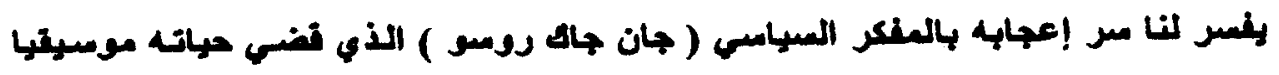

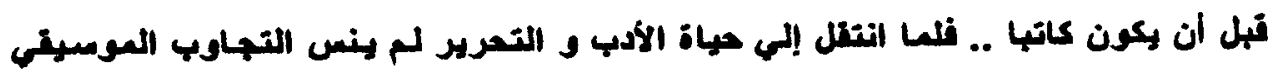

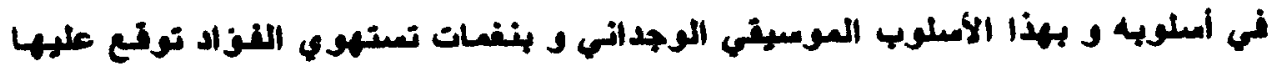

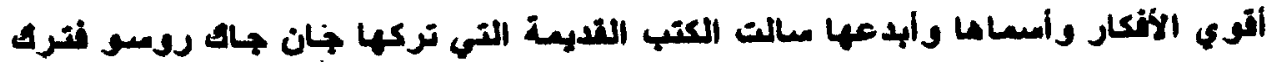

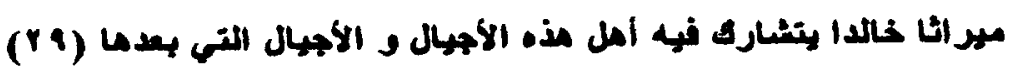

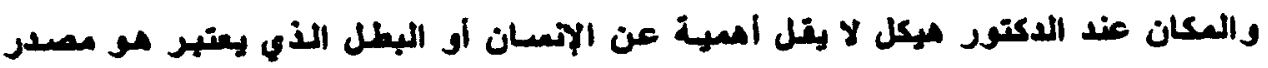

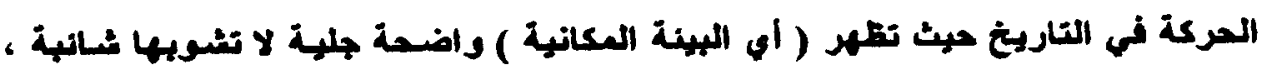

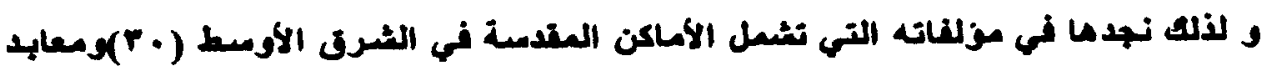

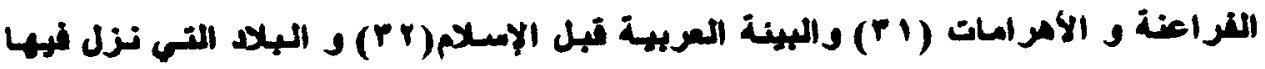

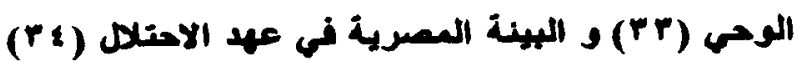

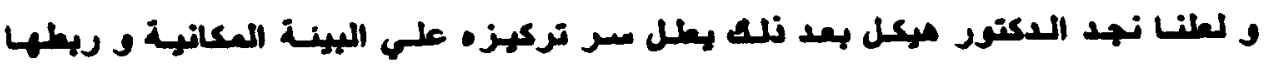

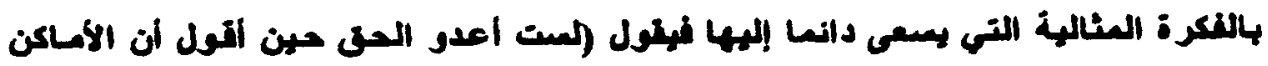

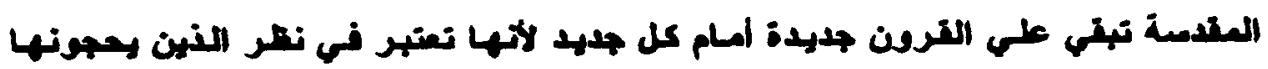

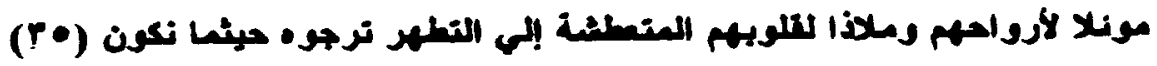

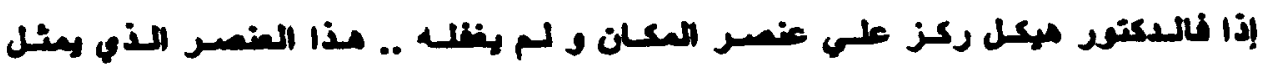

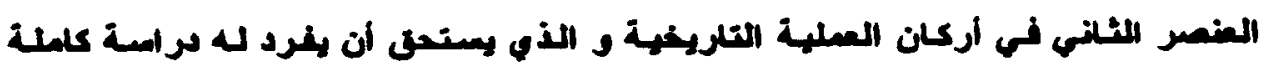
- arring

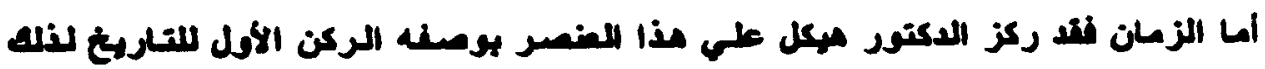

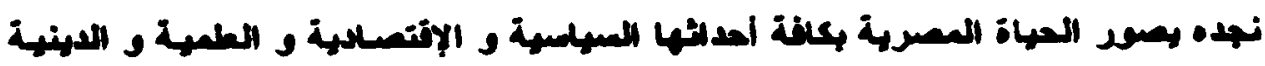

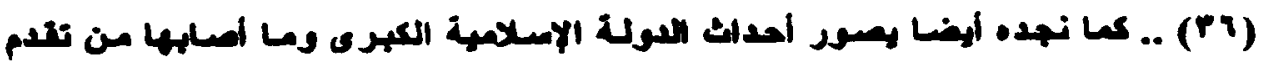

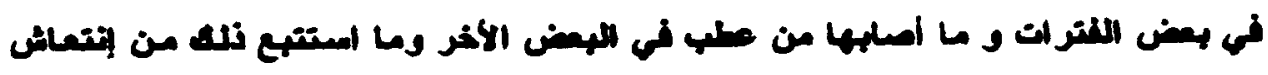




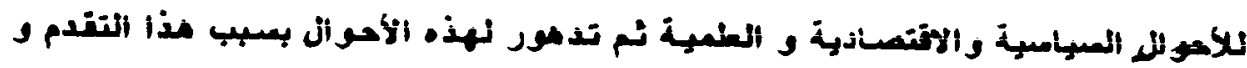
(rv) التدمرد (rv

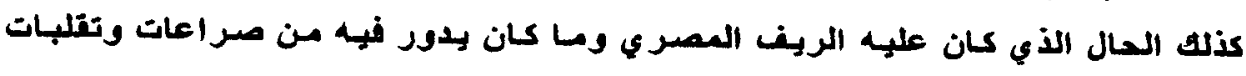

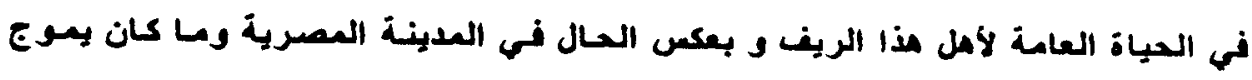

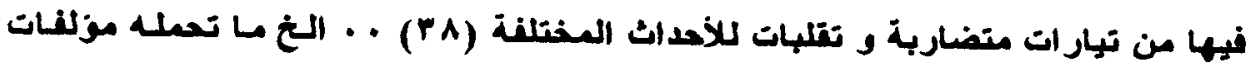

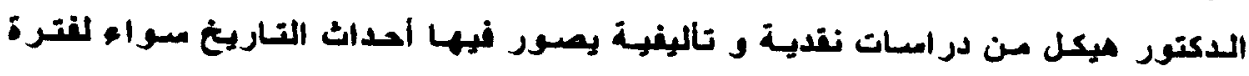

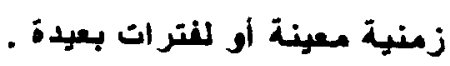

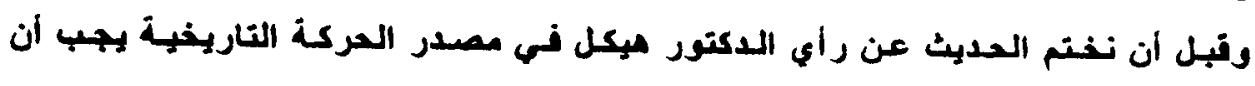

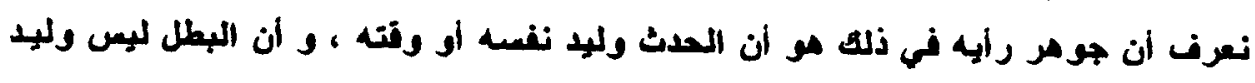

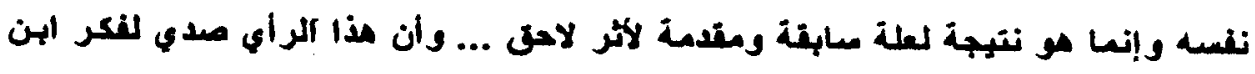

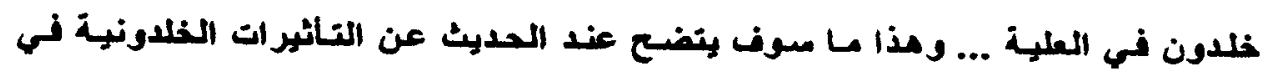

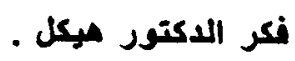

ميكل بين الموضوعية والذاتية :-

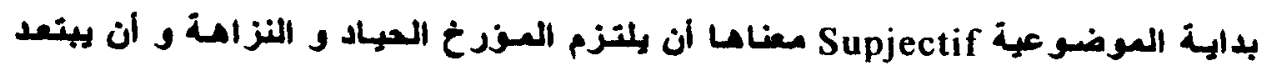

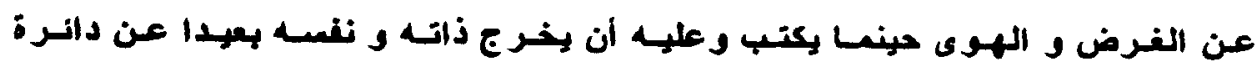

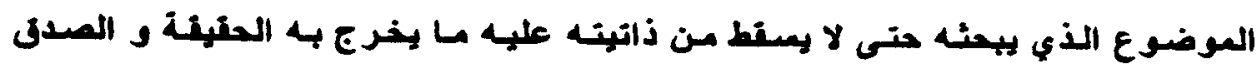

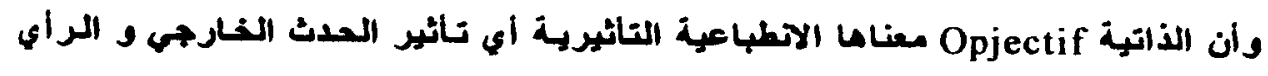

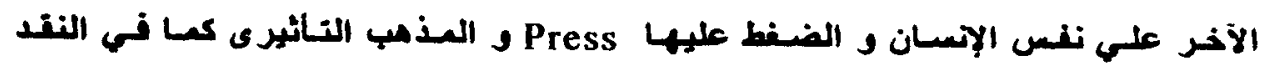

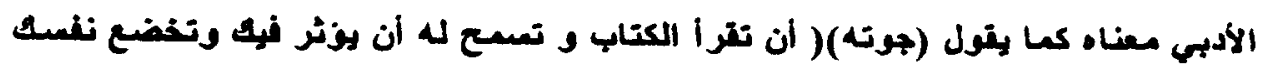

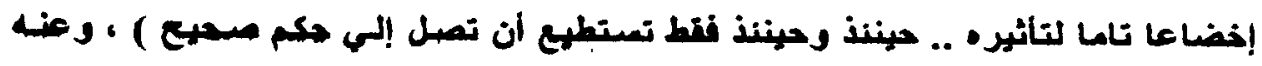

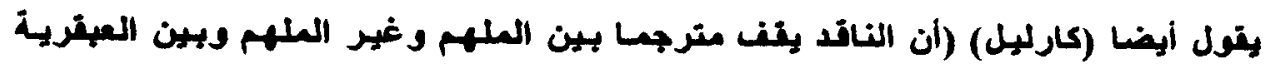

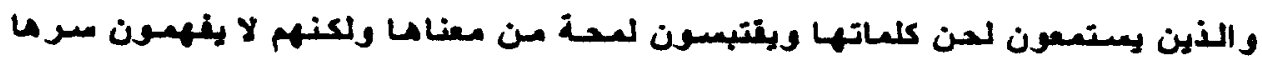

العميق (Pq)

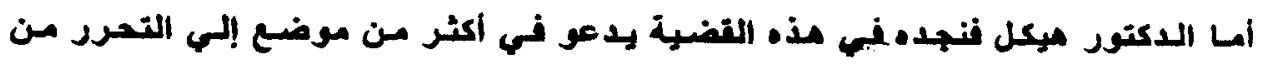

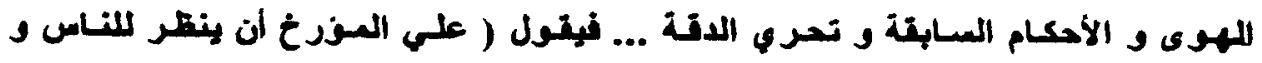

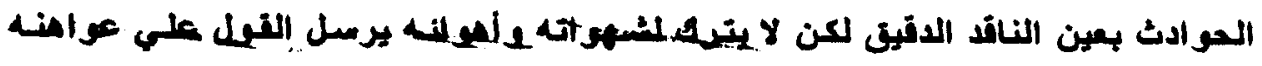




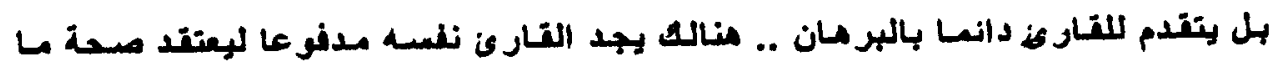

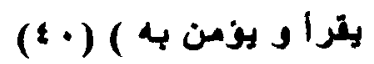

إذا فهر بطالب من بتصدى للتاريخ بان يلتزم الحردة التامسة فلا يمبل به به الهوى فيغير

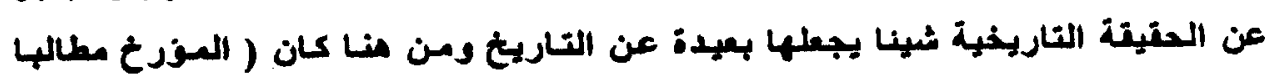

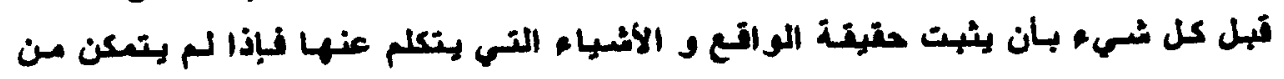

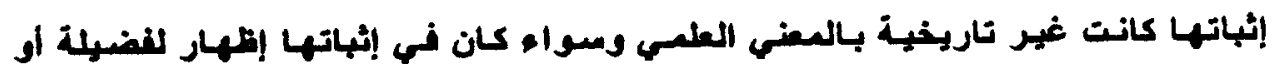

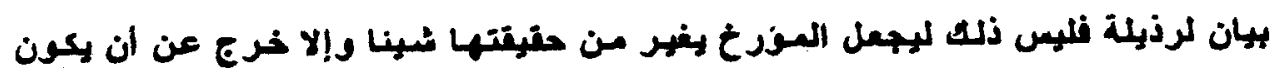

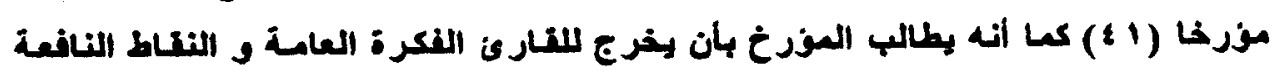

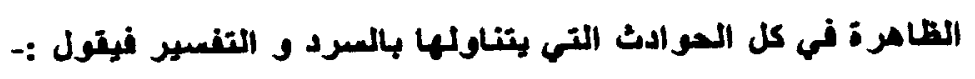

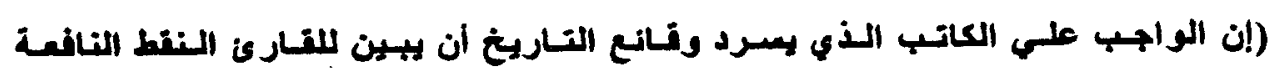

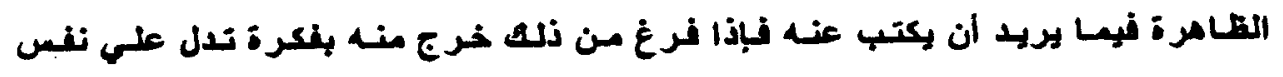

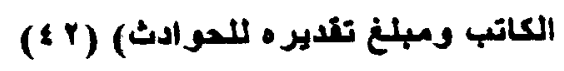

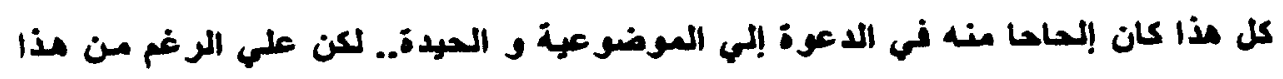

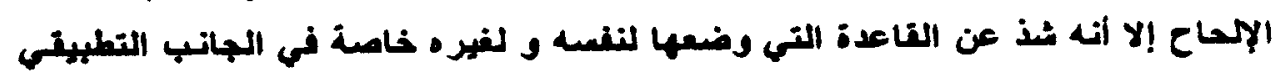

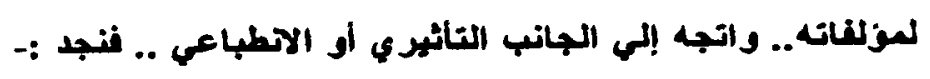

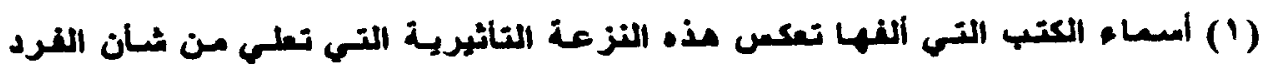

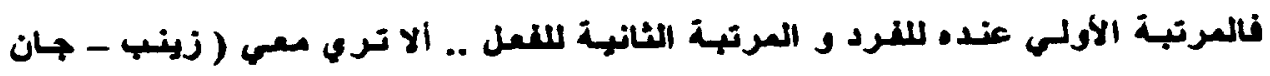

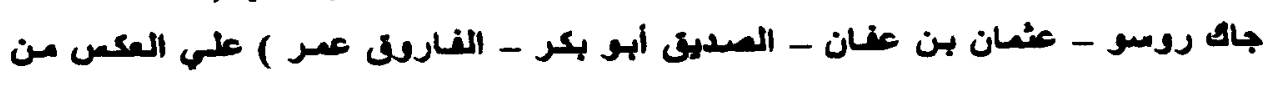

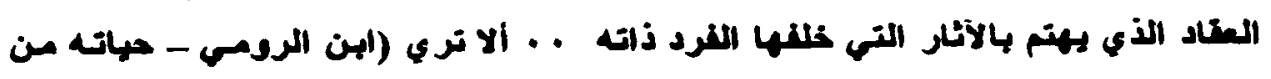

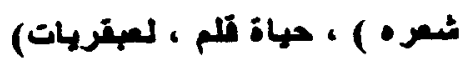

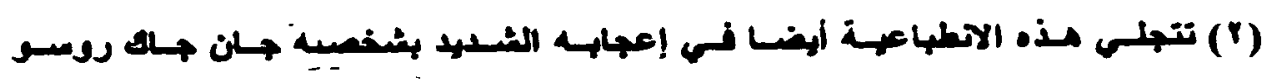

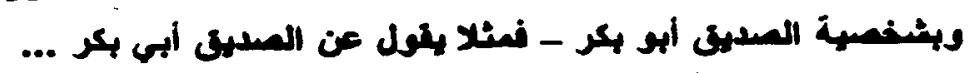

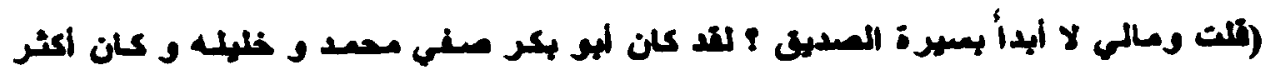

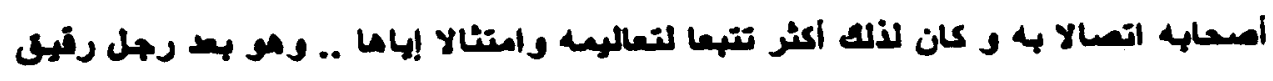

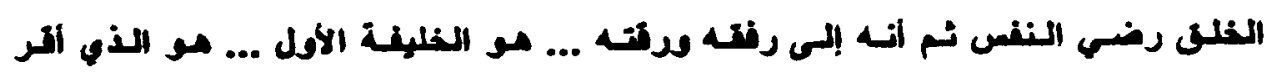

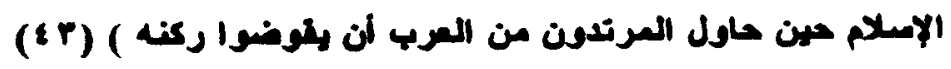

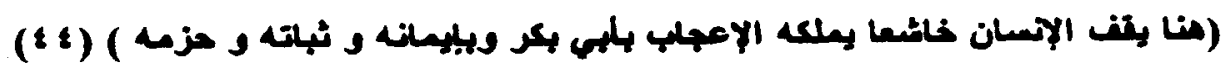




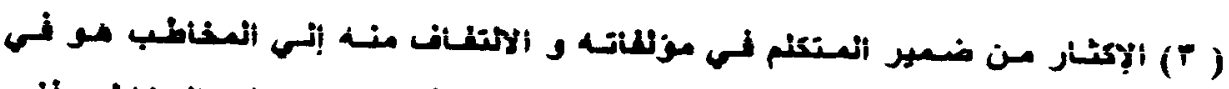

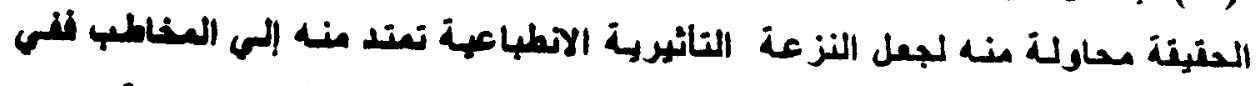

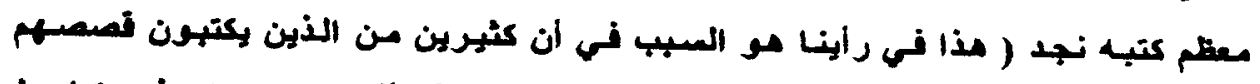

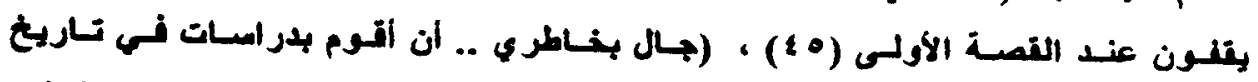

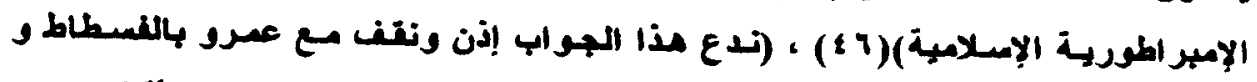

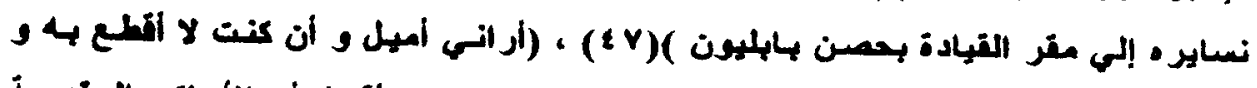

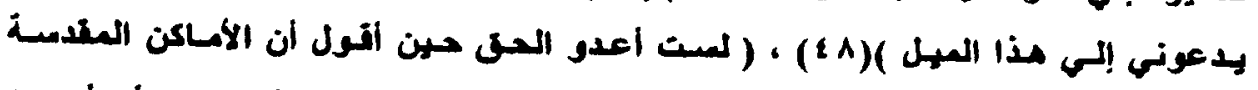

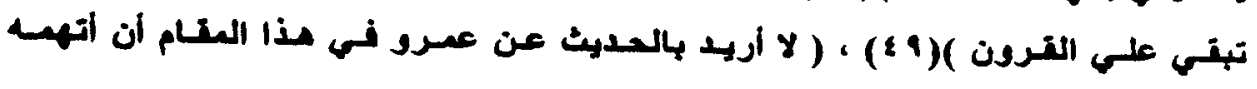

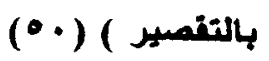

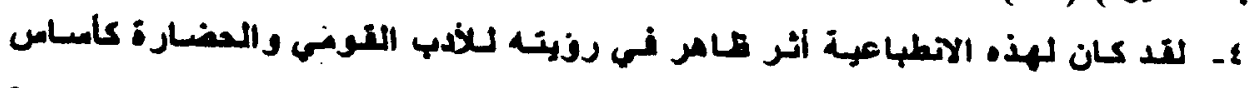

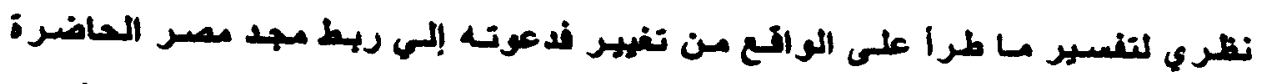

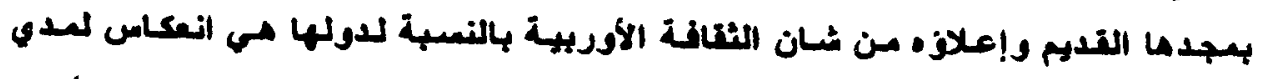

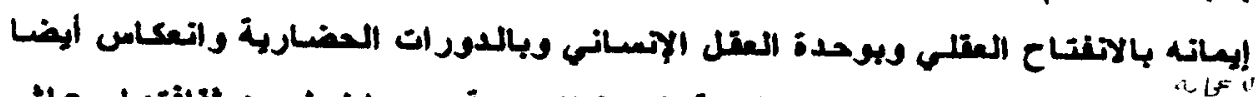

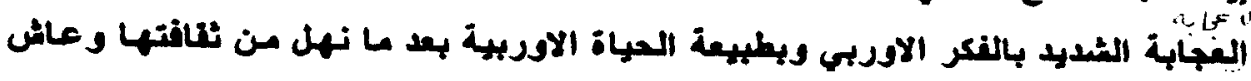

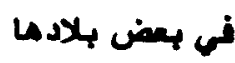
إذا فكل ما سيت بلدعونا إلى التول بان الدكتور موكل مورخ انطباعى تائر ي ننان

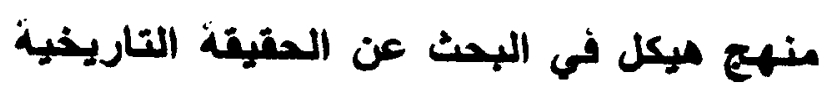

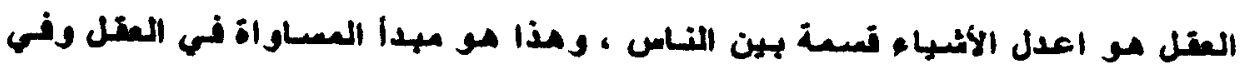

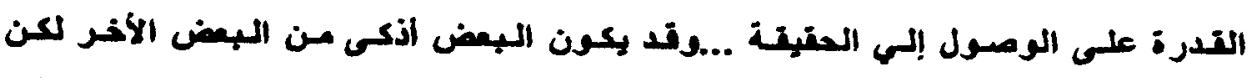

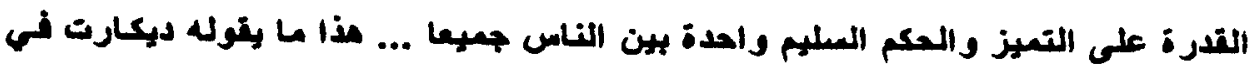

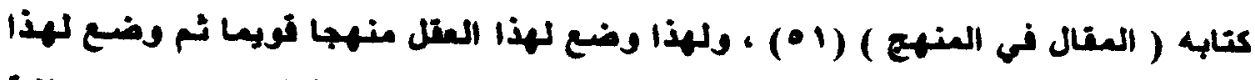

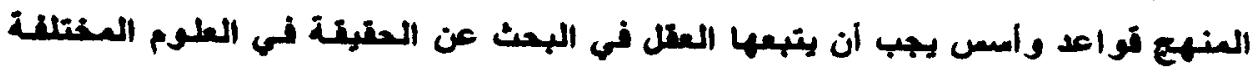

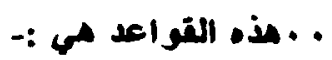

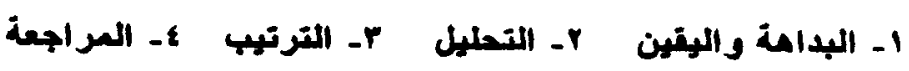

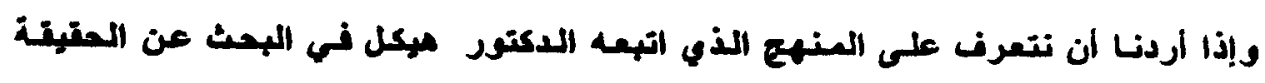

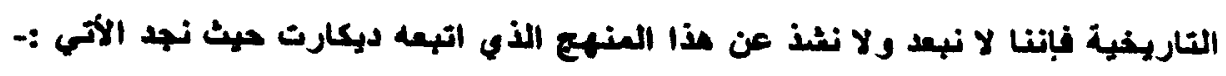




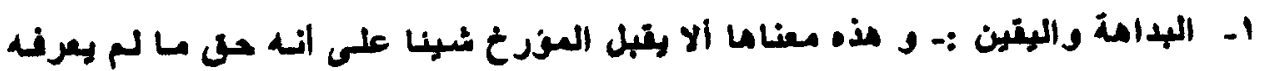

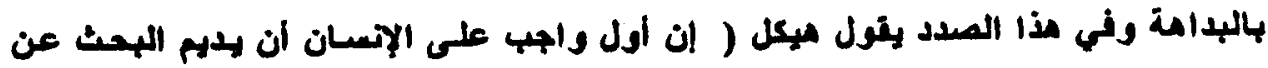

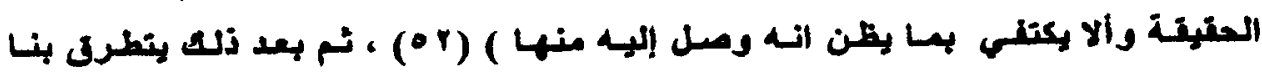

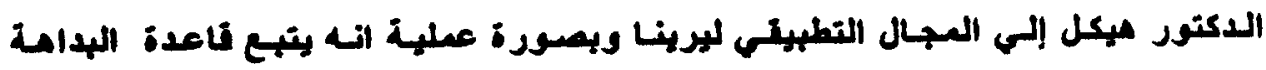

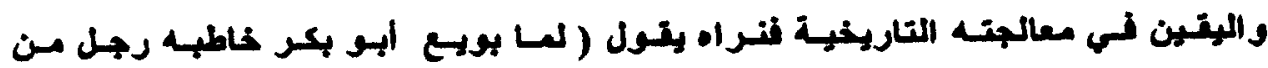

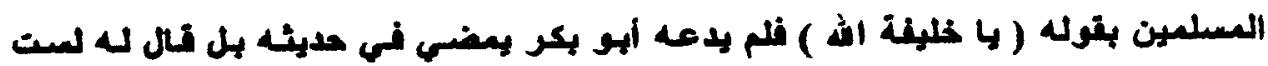

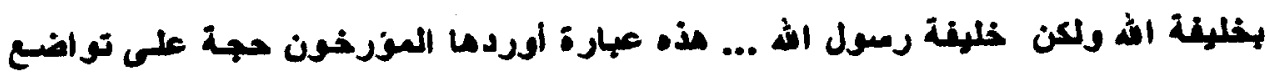

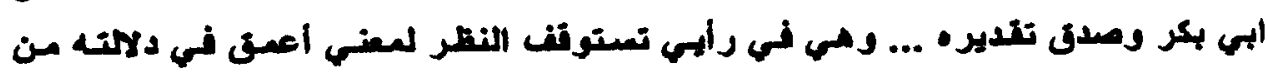

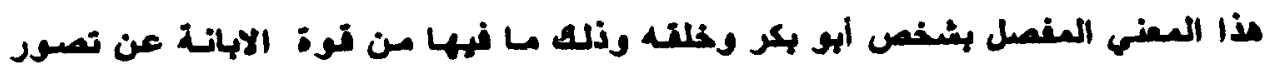

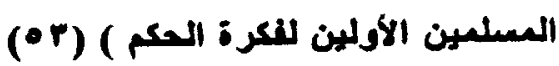

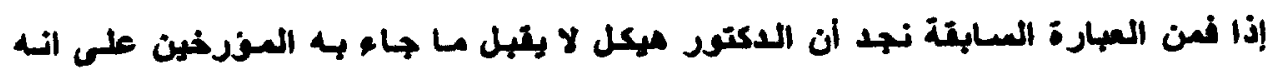

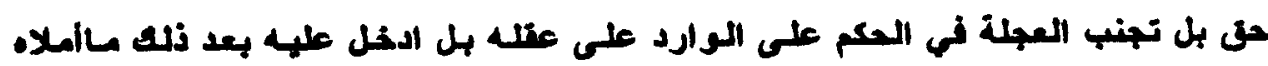
atic

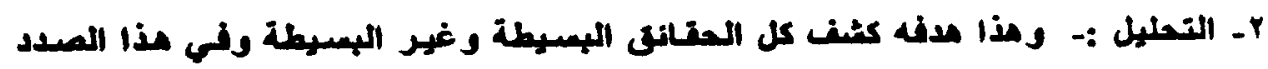

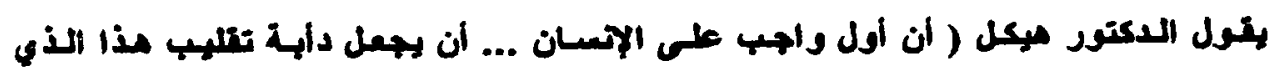

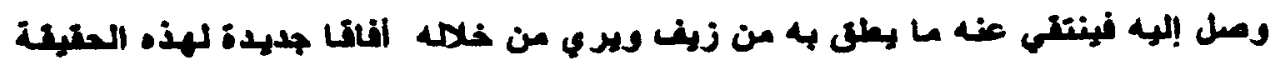

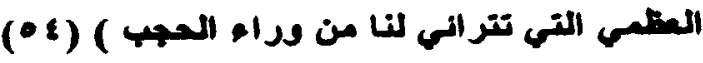

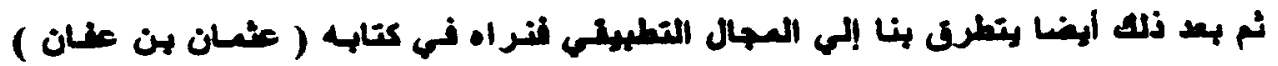

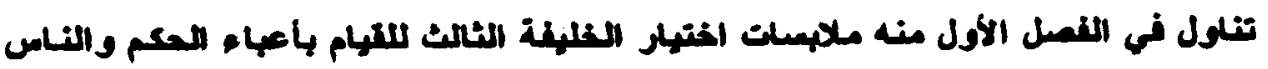

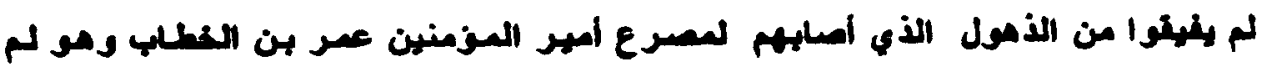

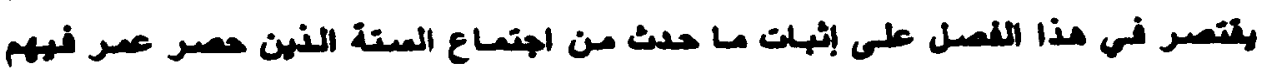

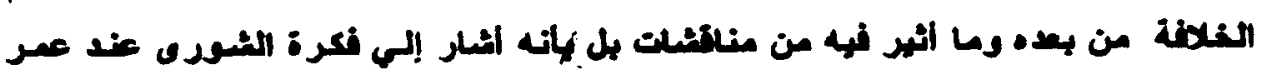

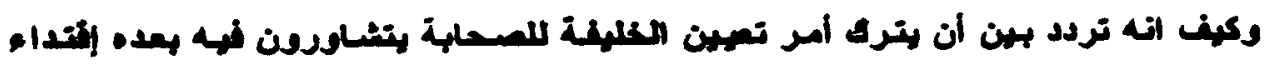

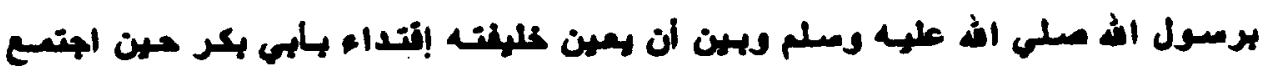

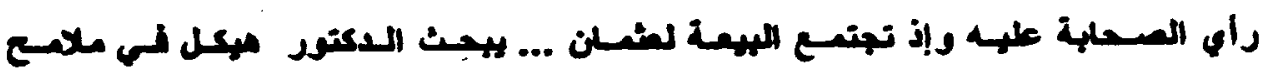

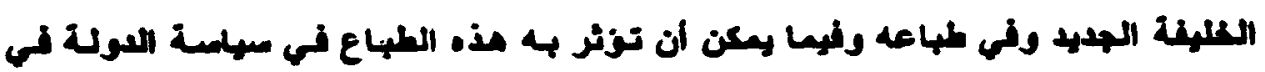




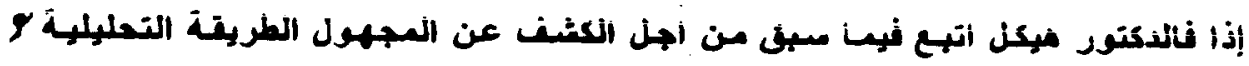

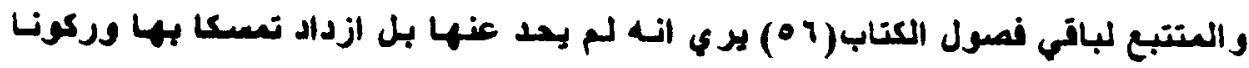

$$
4+1
$$

r- الترتيب :- رهذه ير اد بها ان نرتب أفكارنا فنبدأ بابسطها ثم نتدرج مليلا حتهى نصل

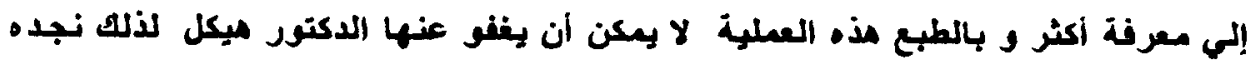

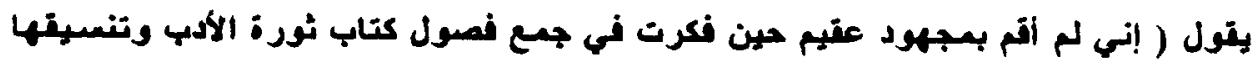

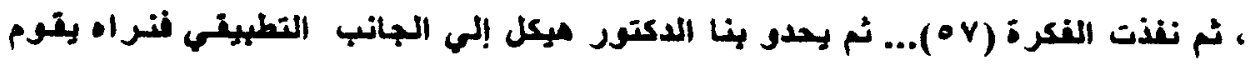

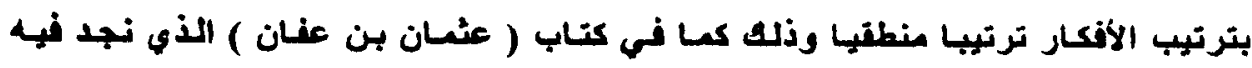

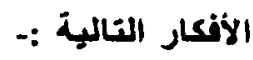
- حديث الشورى وبيعه عثلان

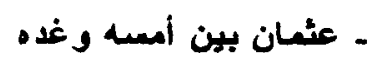

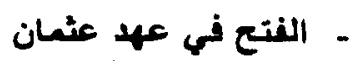

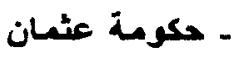
ـ نهاية حياة عثلن فئن ـ- العر اجعة :- بالطبع هذه القاعدة تهدف إلهى التاكد من أن عملبة الترتيب لم تغلـل

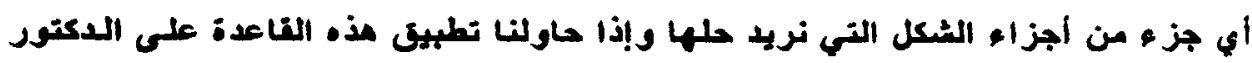

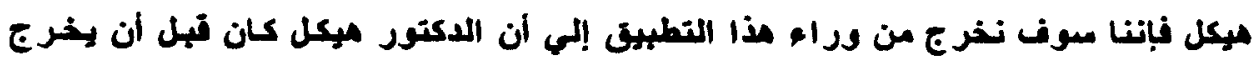

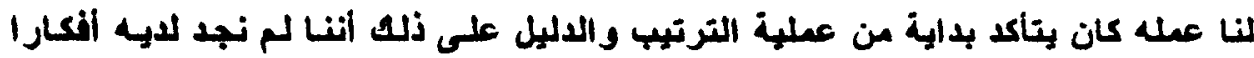

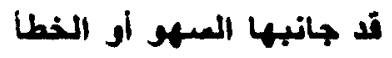
التأثيرات الخلدونية في فكر الدكتور هيكل :-

بعتبر عبد اله بن خلدون وفكر علامة بارزة على قدرة العتلبة العربية على التفوق

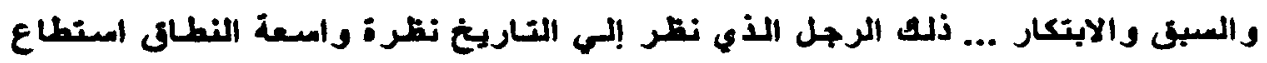

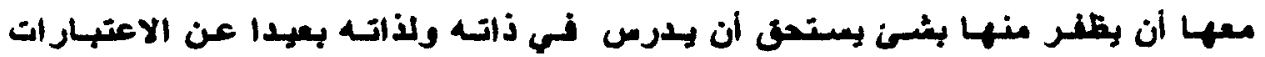

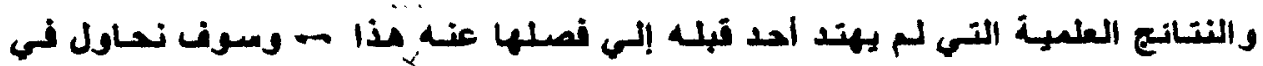
إبجاز ان نلمع بعض الآراء في أكر ابن خلدون رتأثر بها الدكتور هكل فه كتابـة

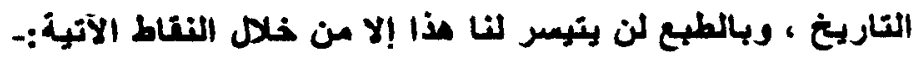




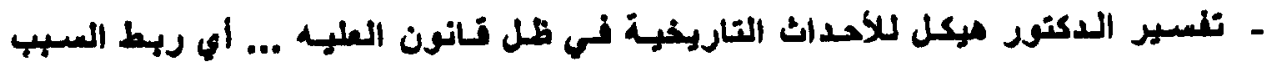

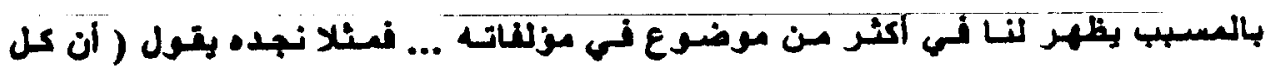

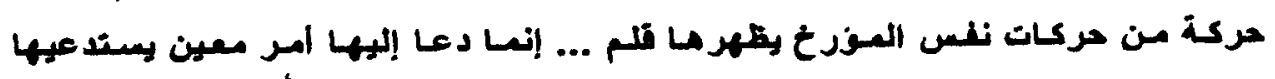

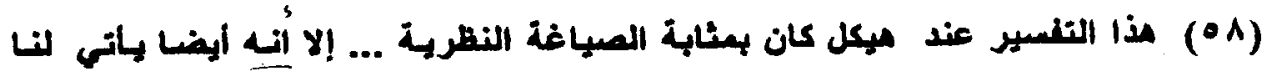

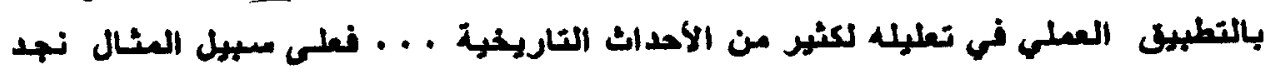

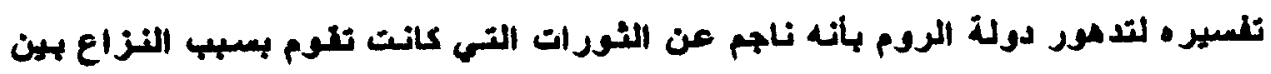

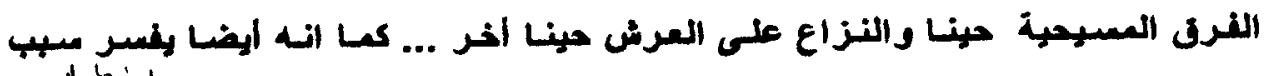

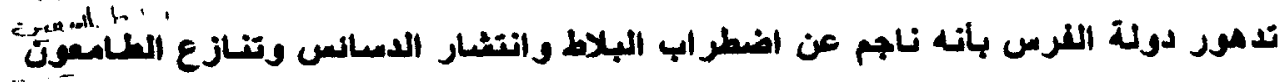

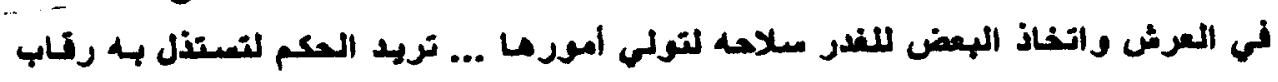

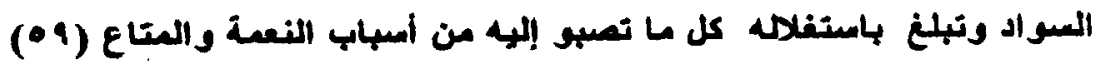

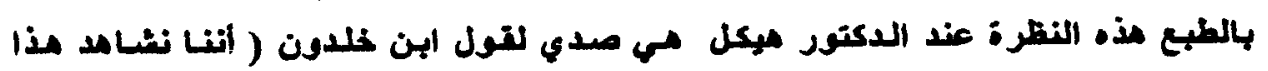

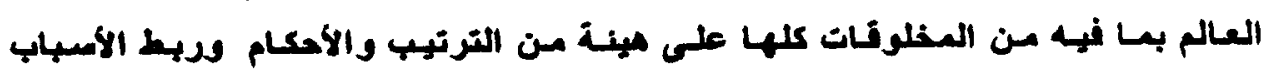

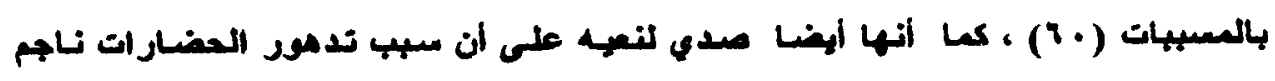

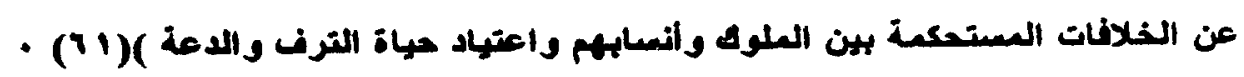

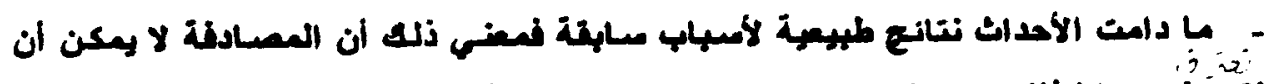

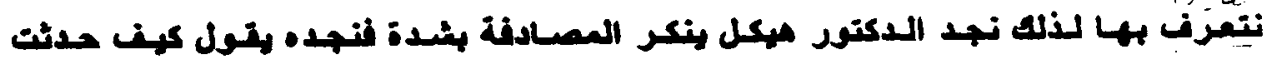

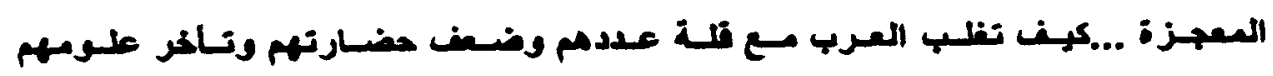

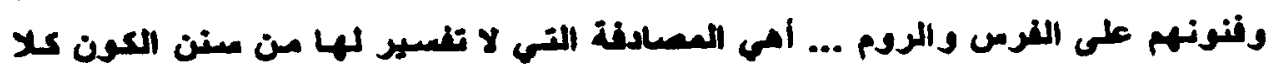

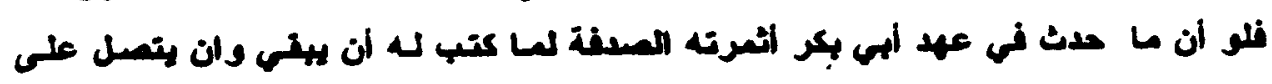

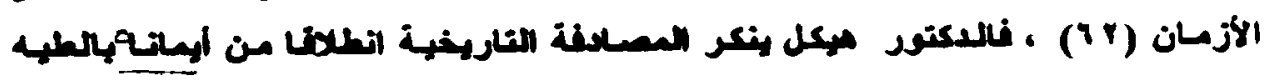

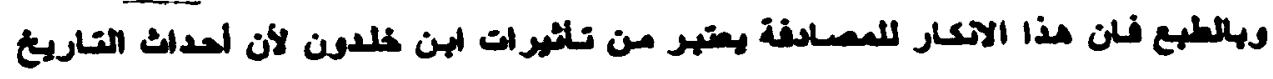

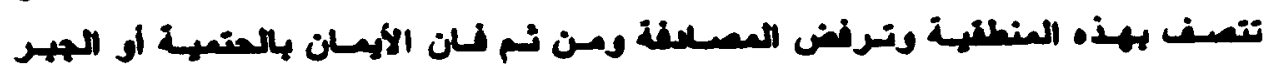

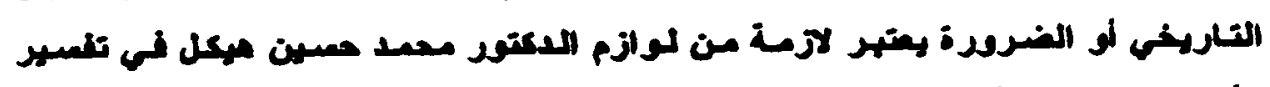

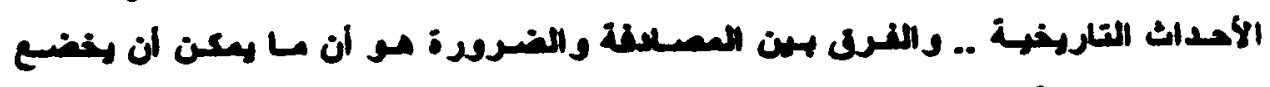

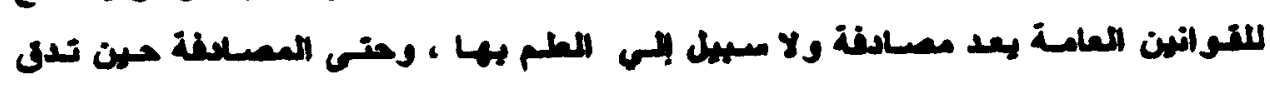

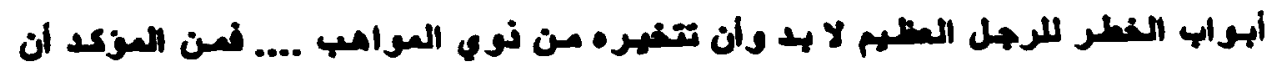

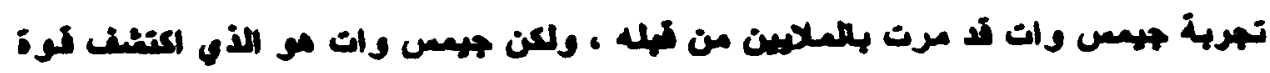

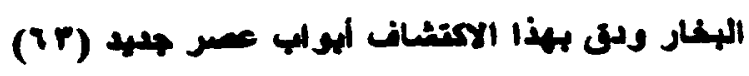




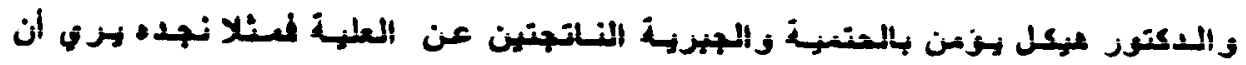

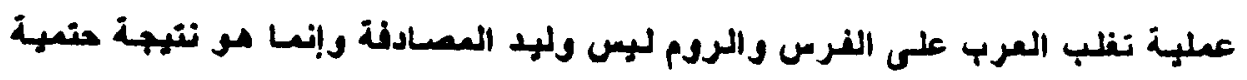

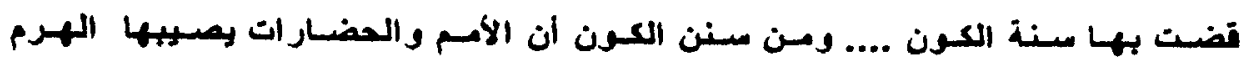

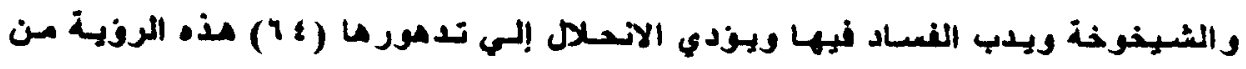

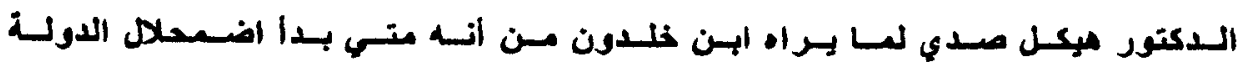

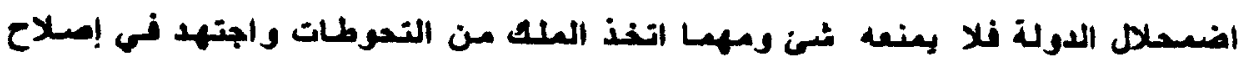

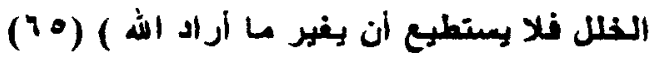

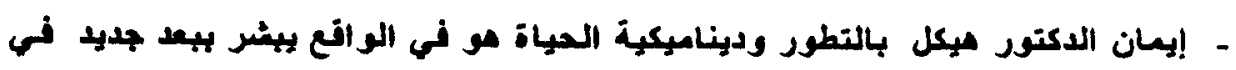

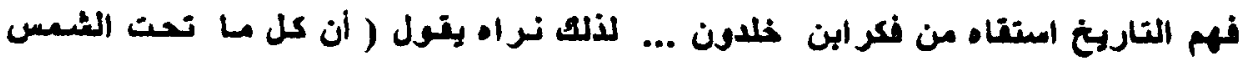

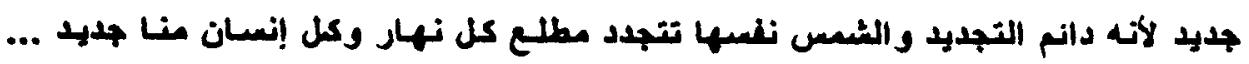

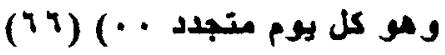

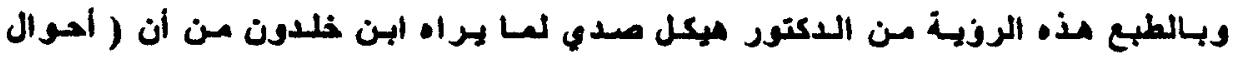

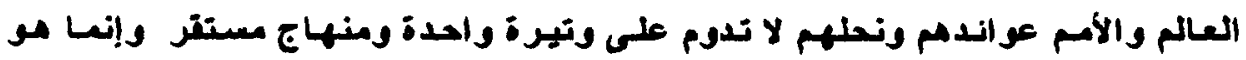

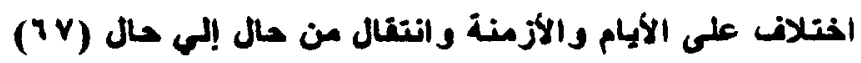

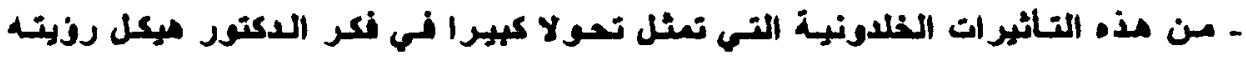

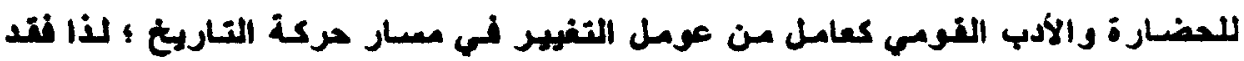

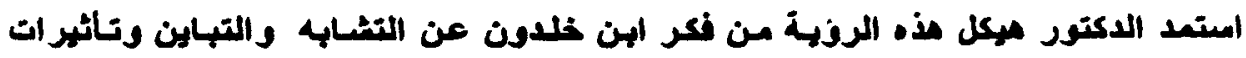

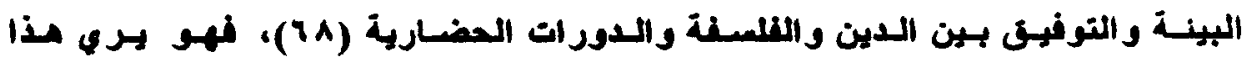

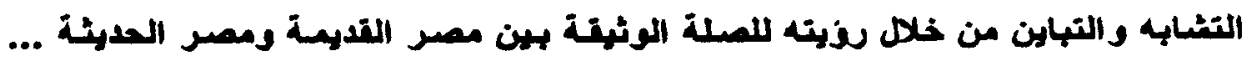

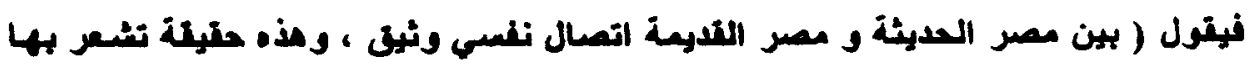

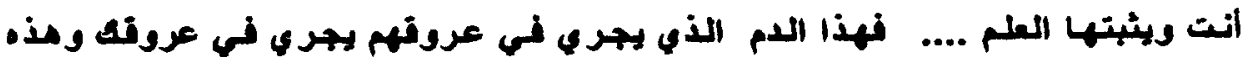

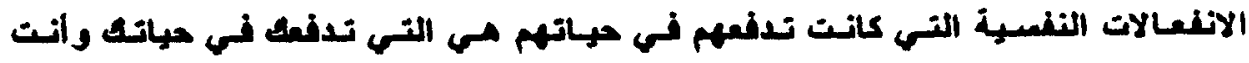

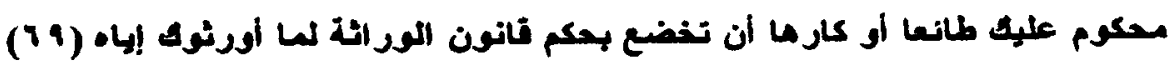

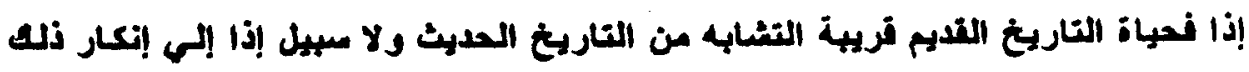

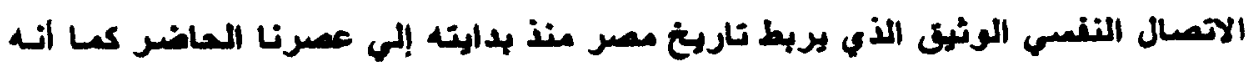

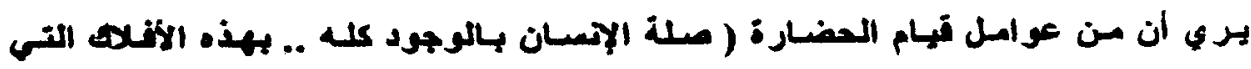

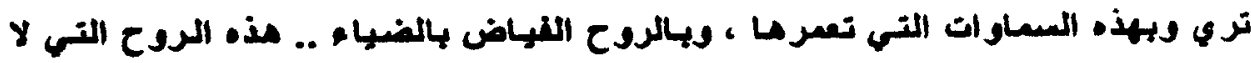

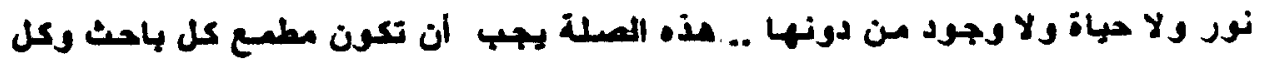




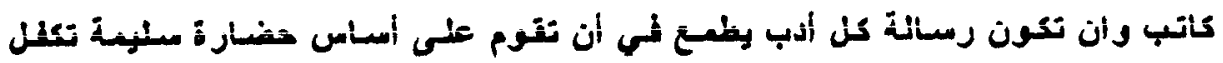

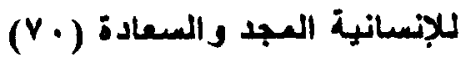

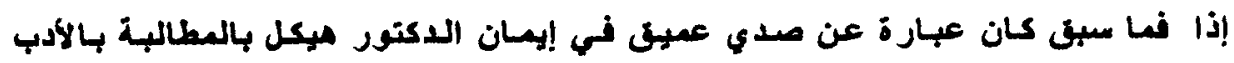

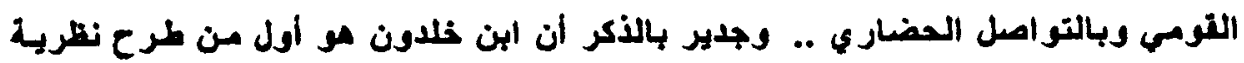

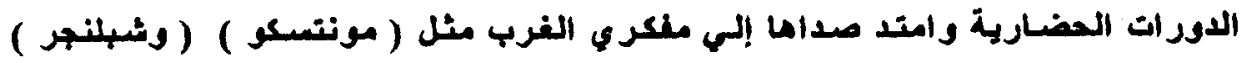

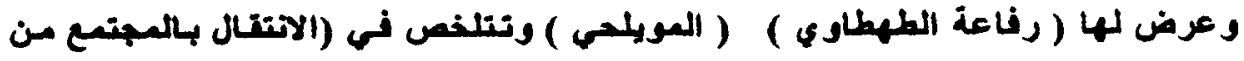

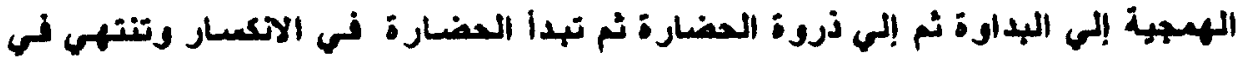

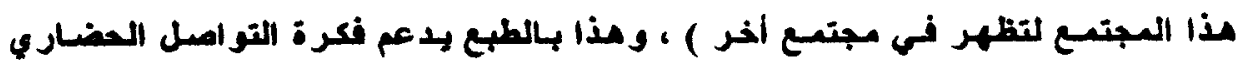

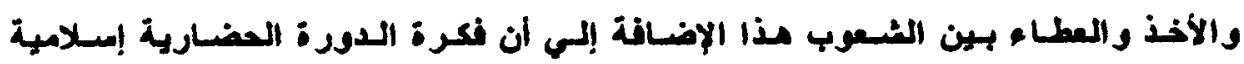

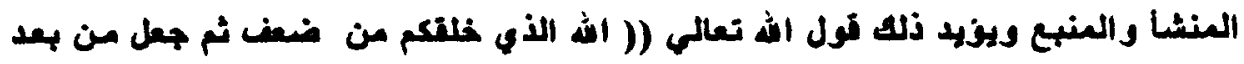

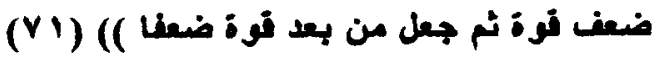

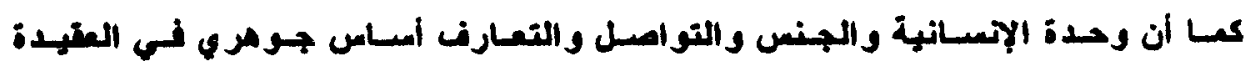

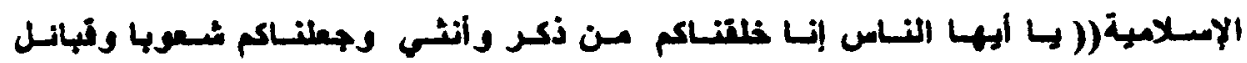

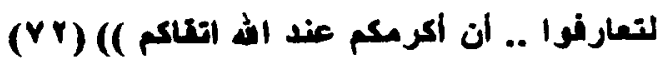

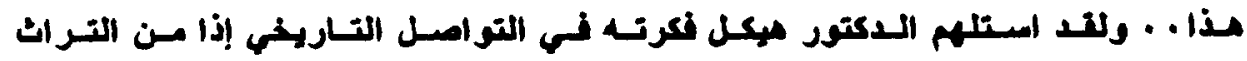

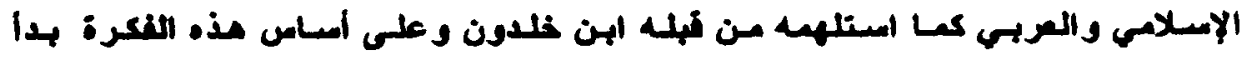

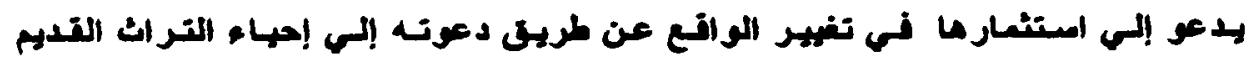

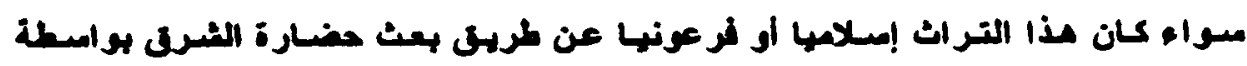

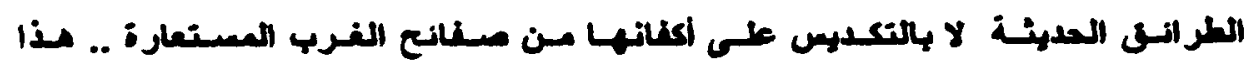

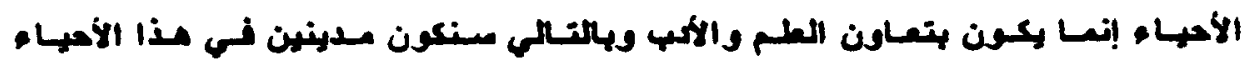

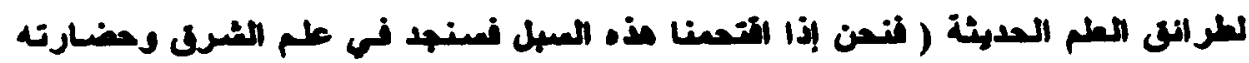

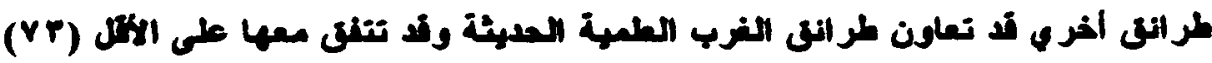

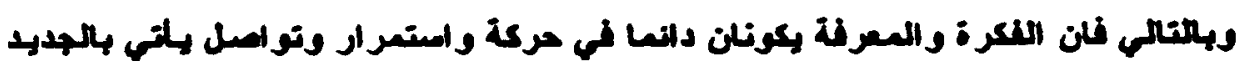

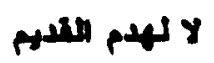
إرادة الإنسان ودور ما في حركن التاريخ عند ميكل 


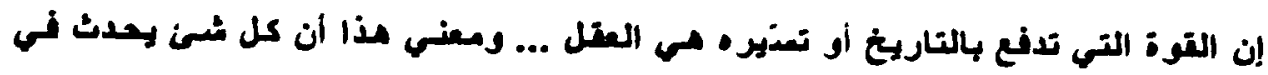

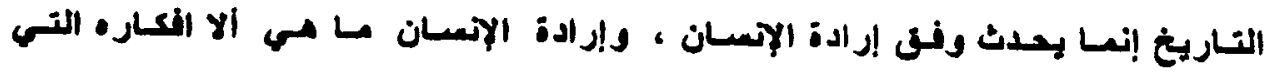

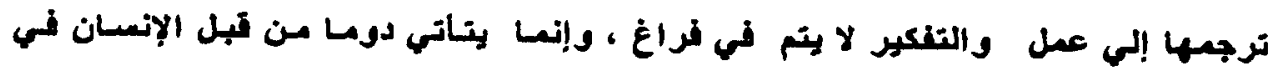

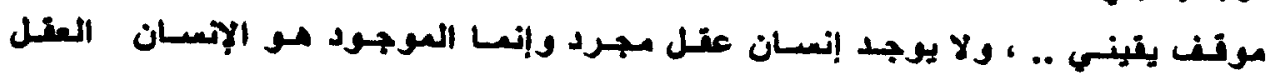

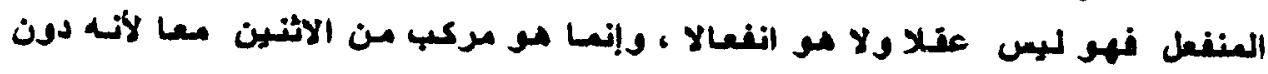

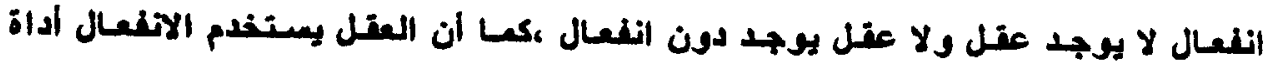

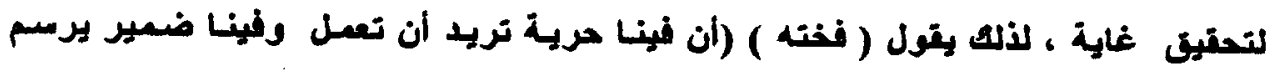

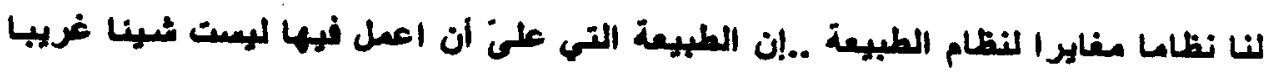

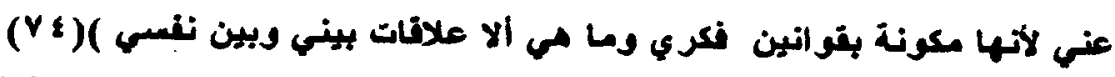

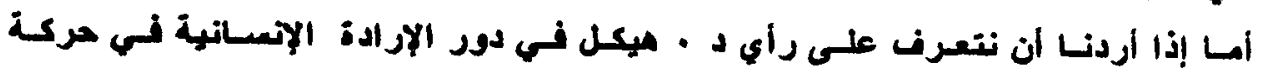

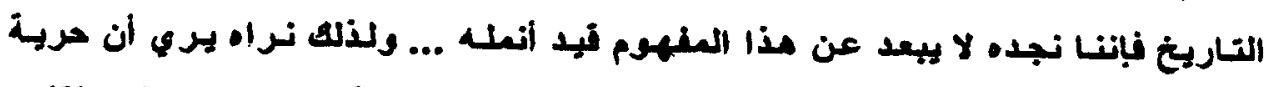

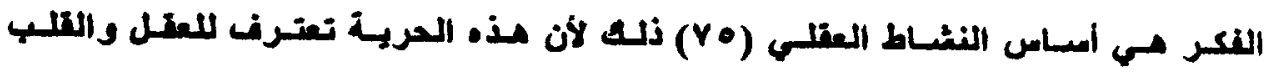

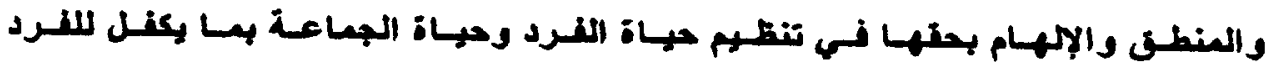

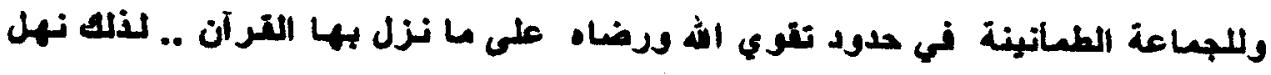

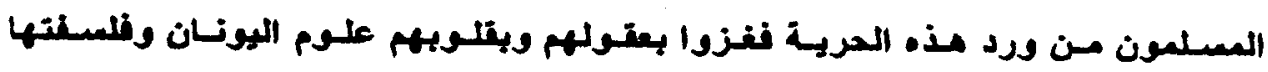

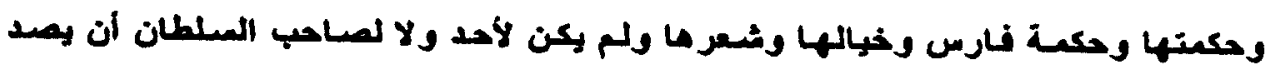

عن ذلك (V)

رمن هنا كان للإنسان الحرية الكاملة في أن بختار الفكرة الته تدفعه لبغلى تصورا

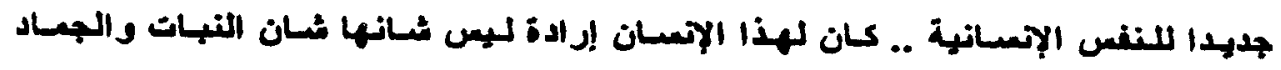

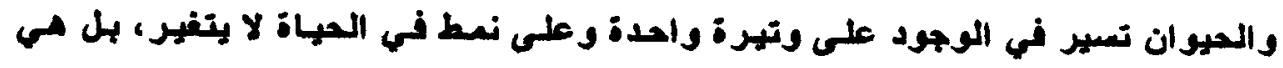

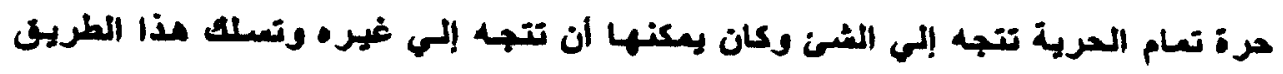

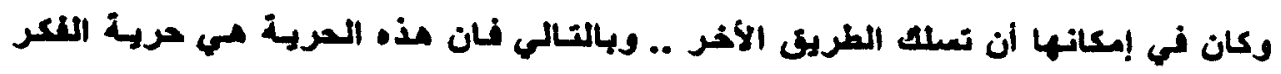

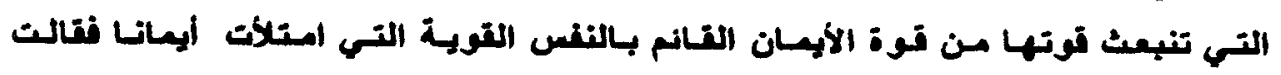

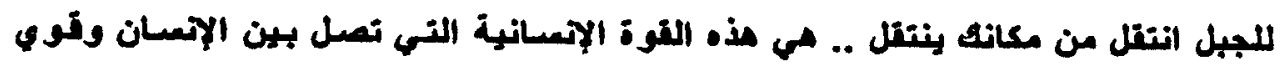

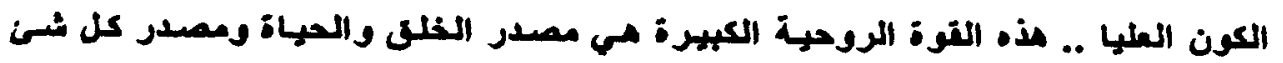

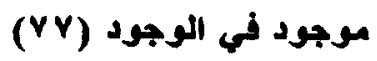




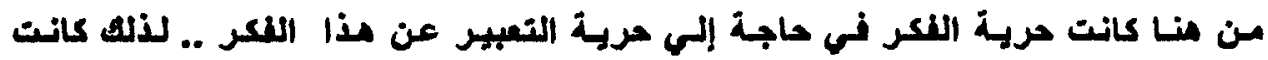

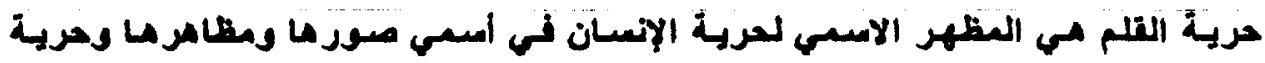

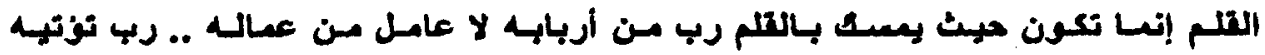

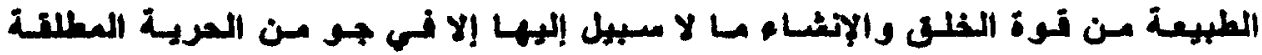

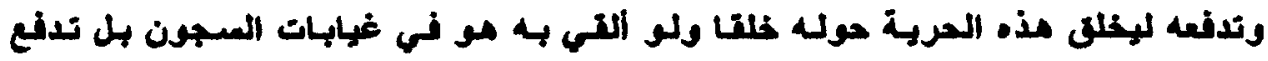

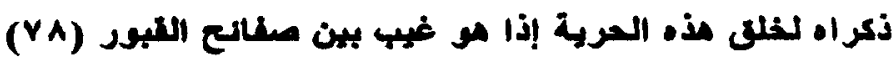

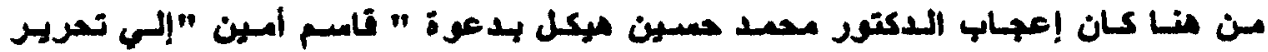

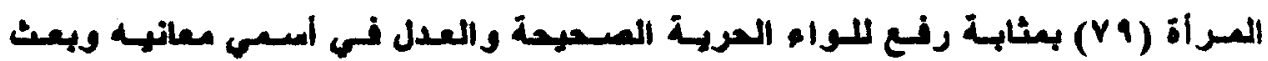

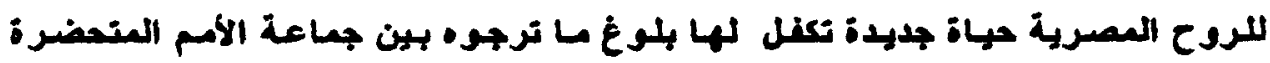

هذا الإتجاز كان على الرغم من القهود الته فرضت على قاسم أمين ومـ لاتـاه من ردود

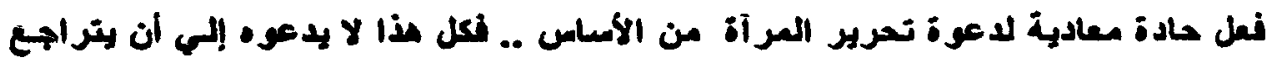

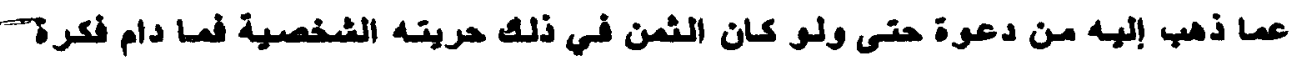

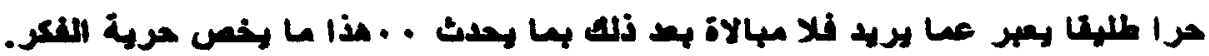

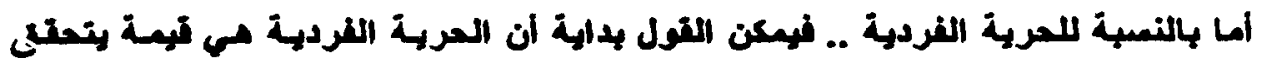

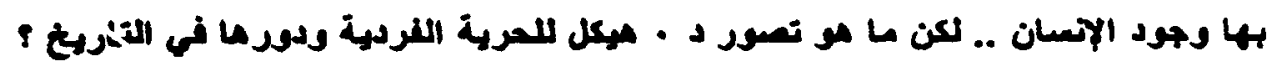

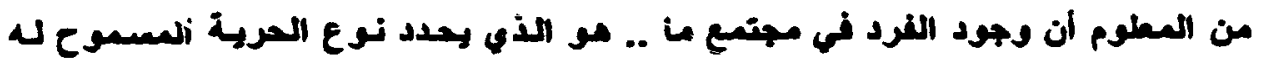

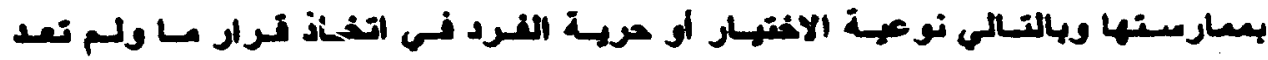

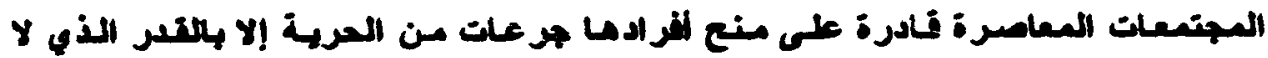

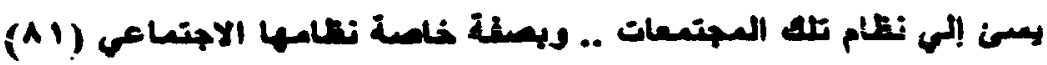

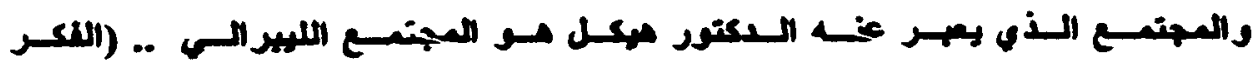

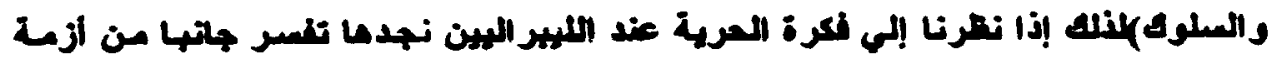

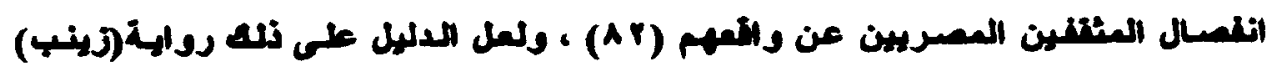

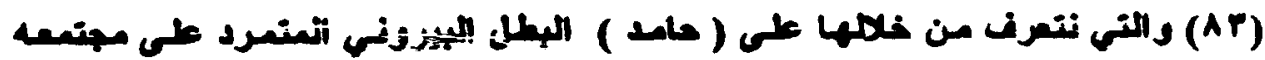

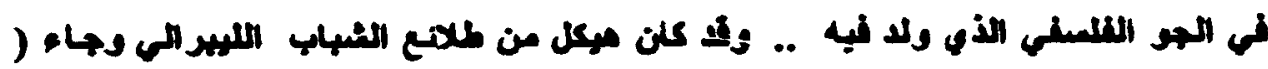

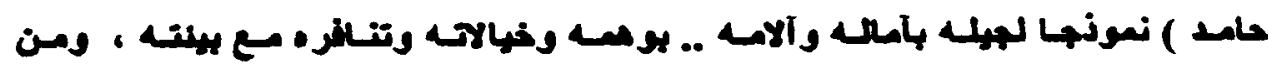

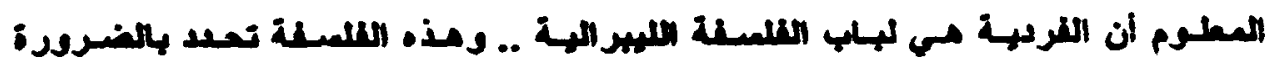




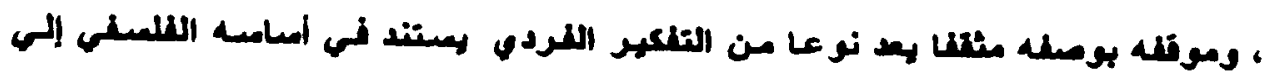

(A (1) (1)

إذا فهذا المغهوم اللهبر المى للحرية بصل بنا إلهى التعلل من لكرة الضرورة الاجتعاعية

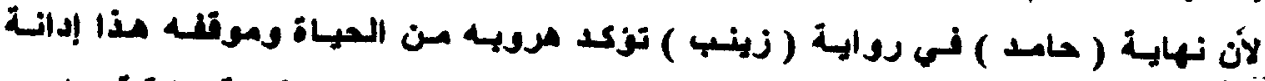

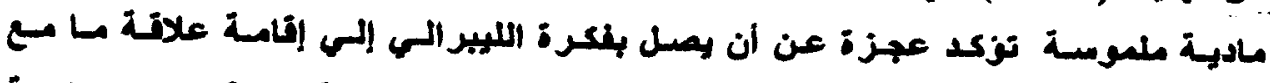

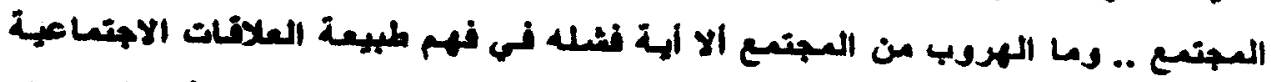

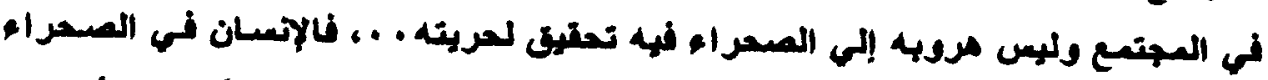

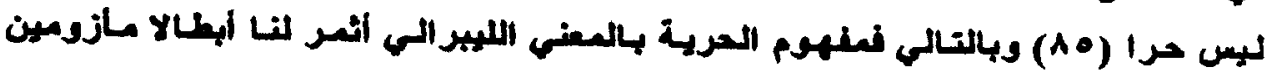

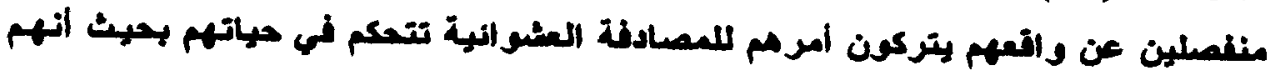

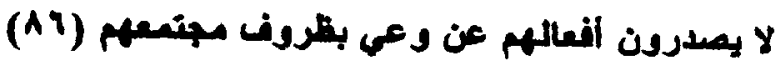

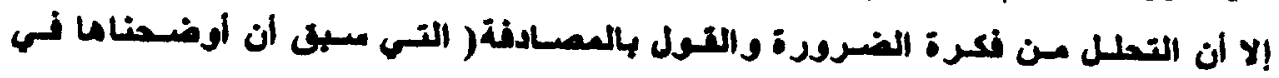

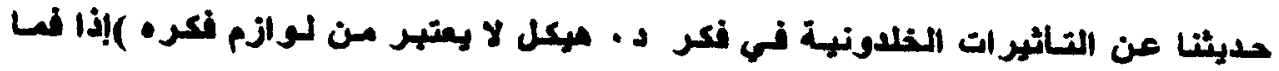

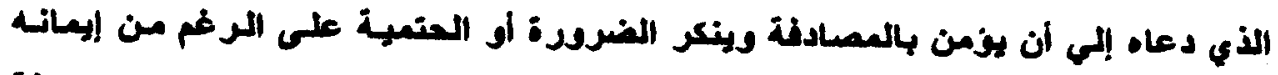

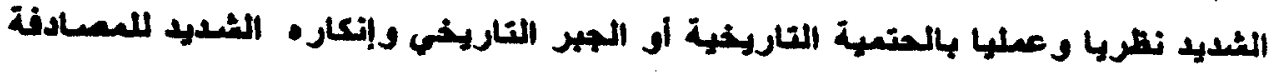

العشواثهة

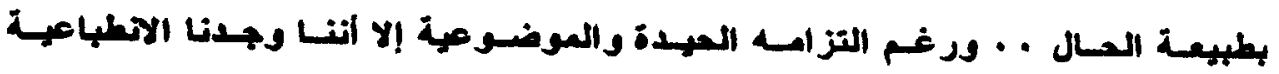

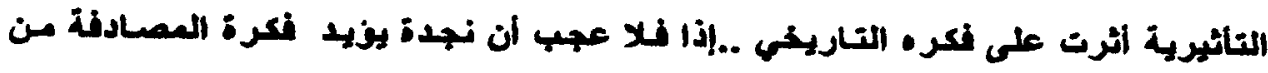

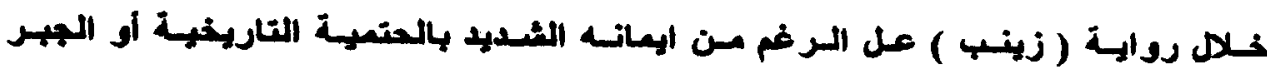
التاريخه.

\section{$2 x=1$}

وهذا للقد اتعست الروح التاريخهة عندالدكتور ميكل بأنها ردح تلاهط وتهرب ثم

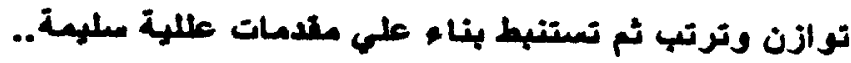

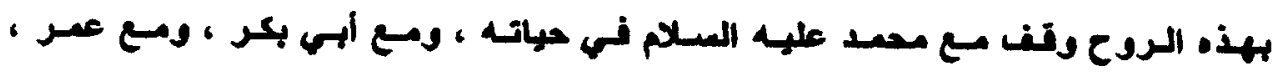

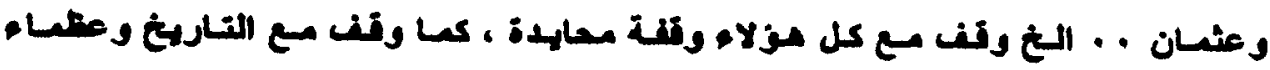

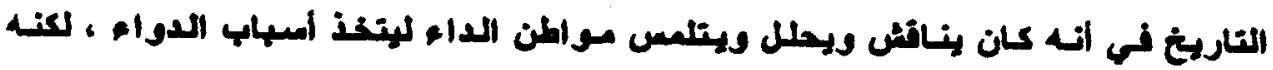

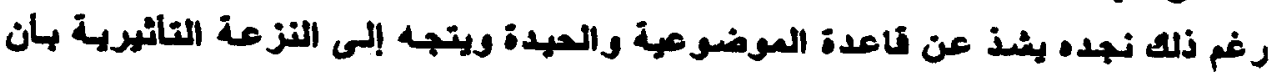


ترق لهواه ان بتدخل فاعجب بشخصبات وادلى برأبه في مواتف وأحداث ومن ثم كان

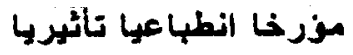
كذلك كان شرى الحدث وليد نغعه أو وتته ، وان البطل ليس ولهد نفسه وإنما مو نتيجة

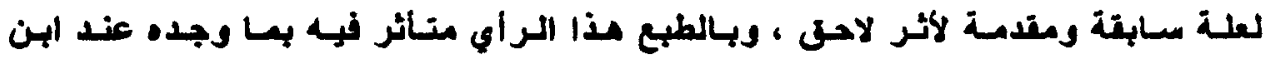

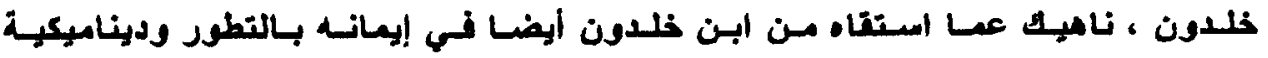

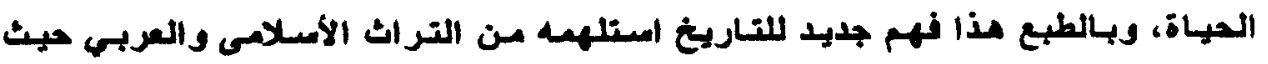

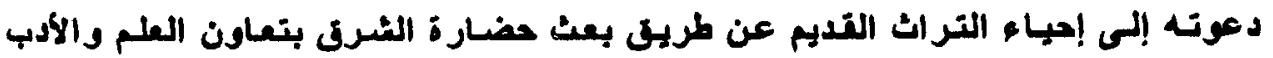

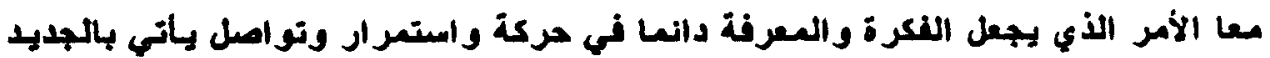

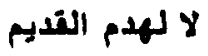

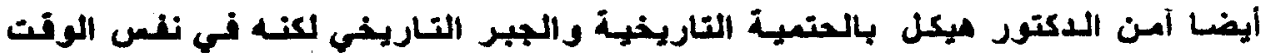

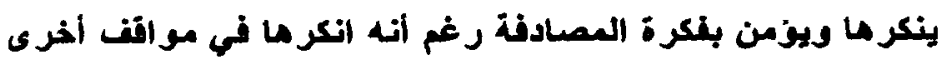

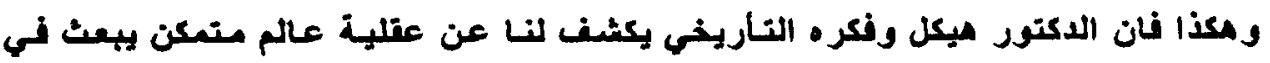

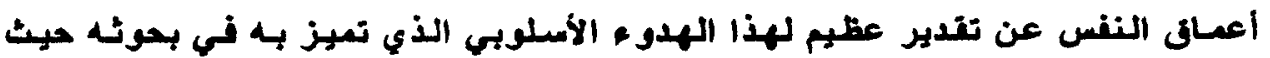

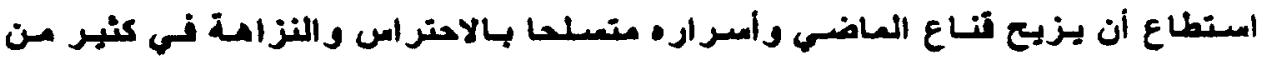

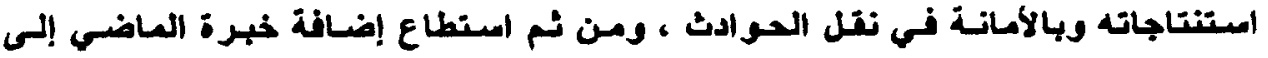

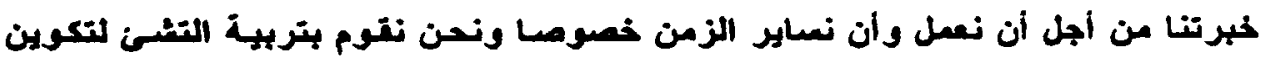
الرجال وبالطبع مذا العصل لن بكون صحيحا إذا نحن جهلنا سـلالة من نربه ومهاك أجدادم

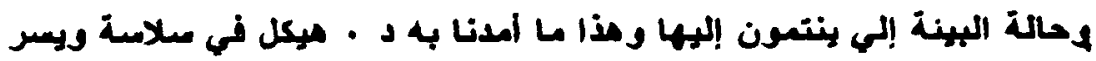




\section{المواشوالمهاده}

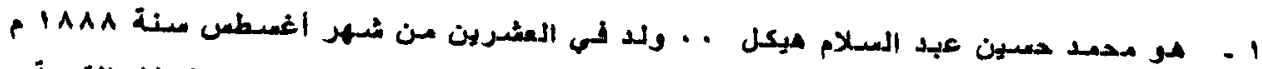

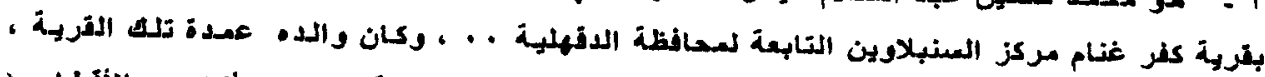

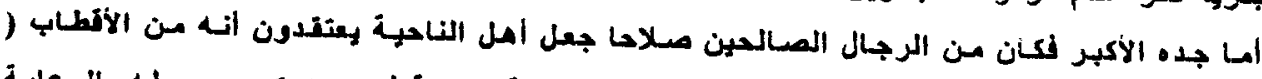

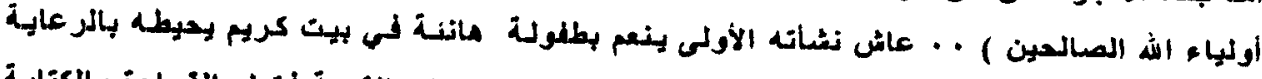

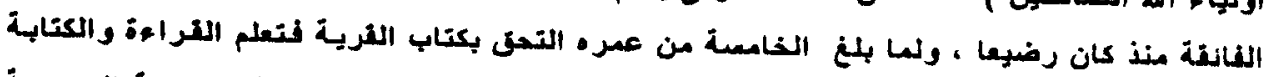

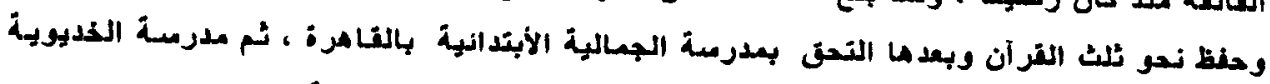

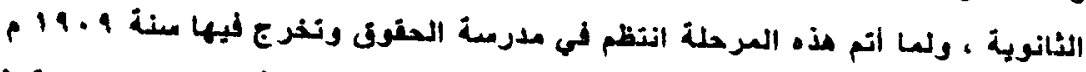

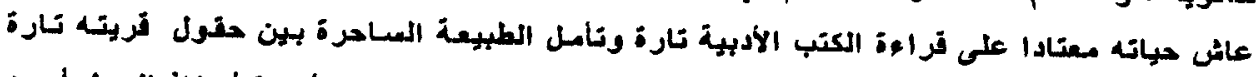

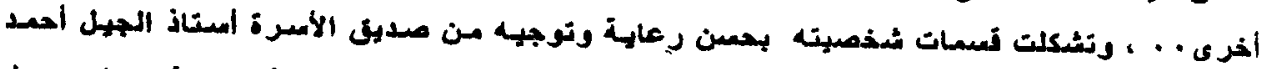

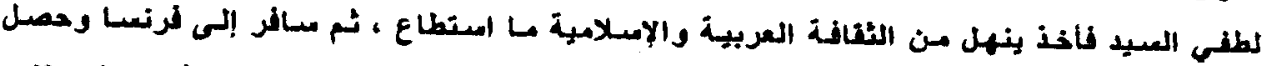

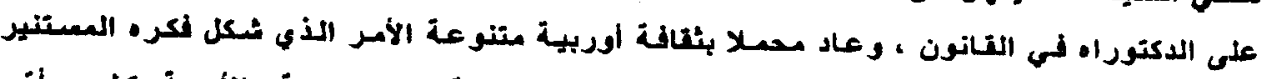

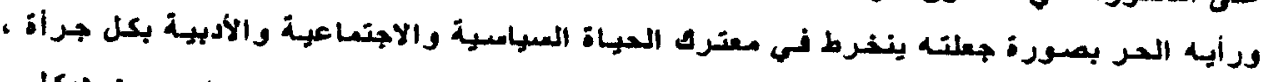

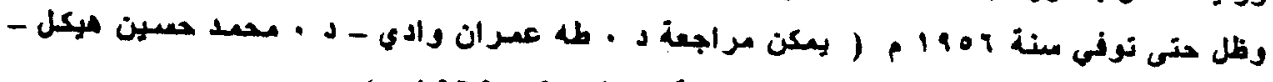

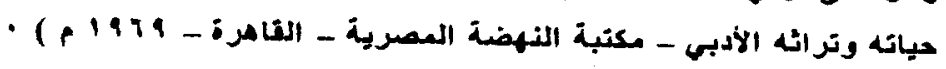

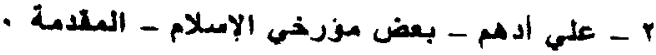

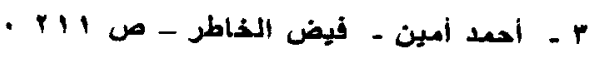

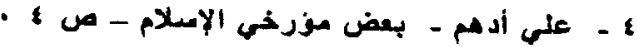

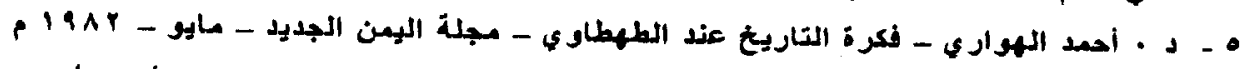

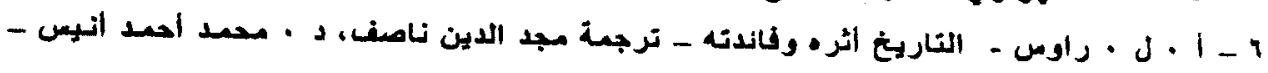
• م 10

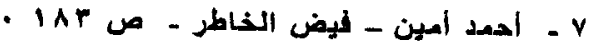

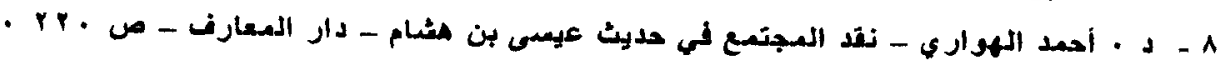

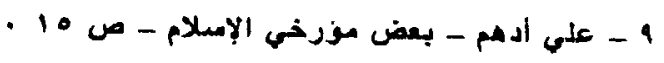

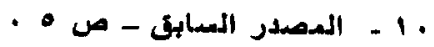$$
11 \text { - } 11
$$

r

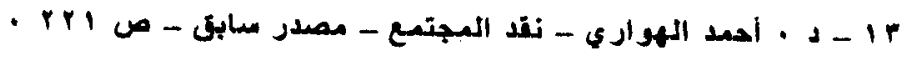




$$
\text { - rr } 4 \text { \& } 18
$$

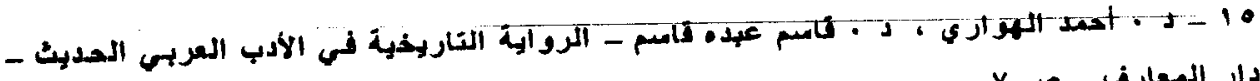

$$
\text { - دار المسارف - }
$$

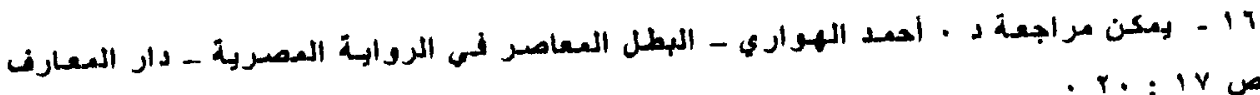
- r. : I r w

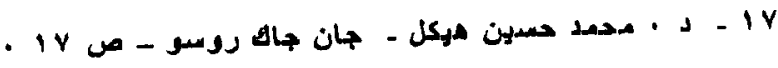

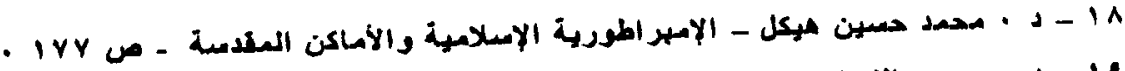
19

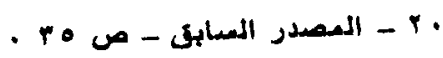

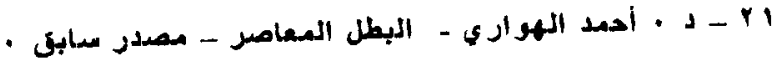

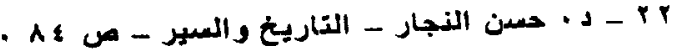
. Or ،

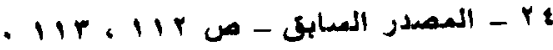

- ro

.

R

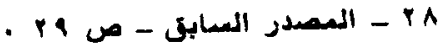

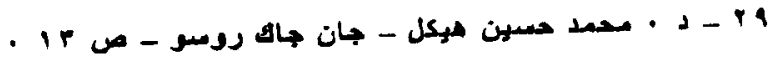

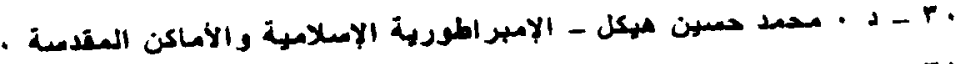

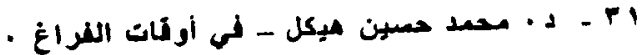
-

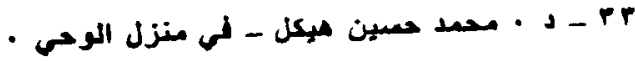

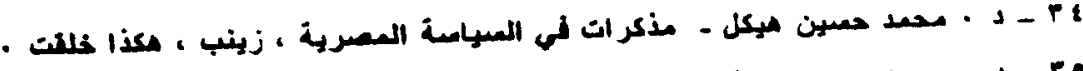

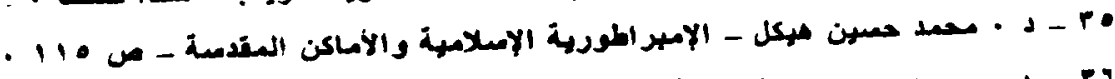

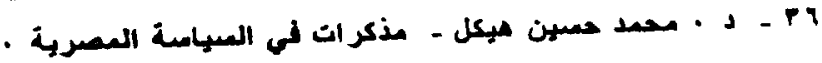

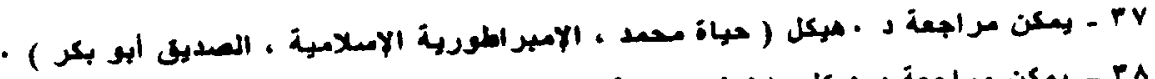

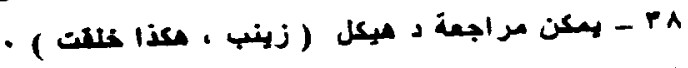

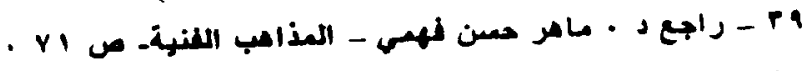

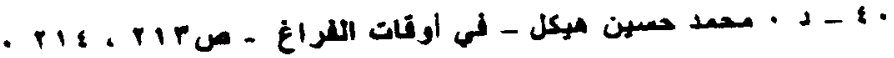

- Pr - 1

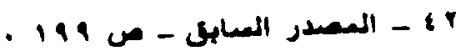

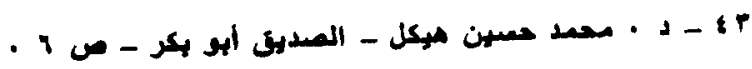




$$
\text { - } 1 \text { | } 1
$$

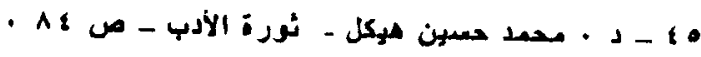

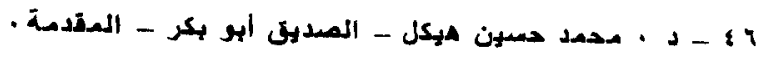

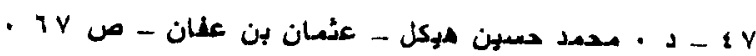

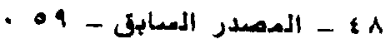

9

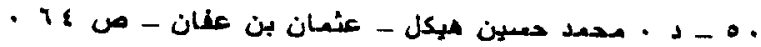

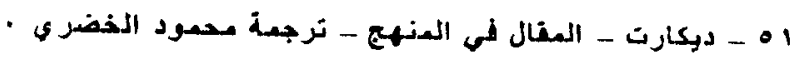

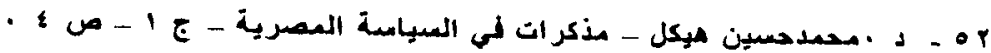

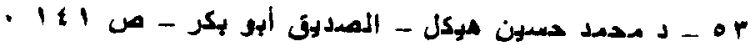

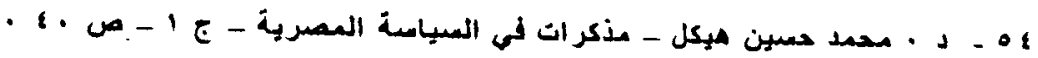

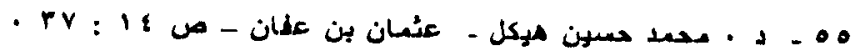

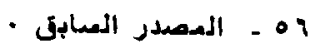

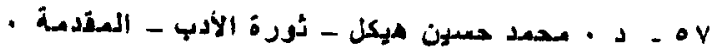

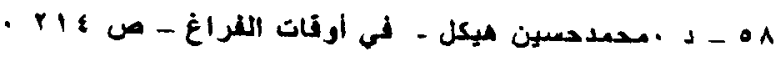

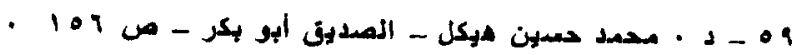

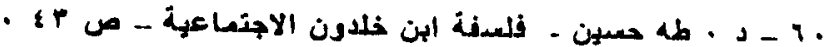

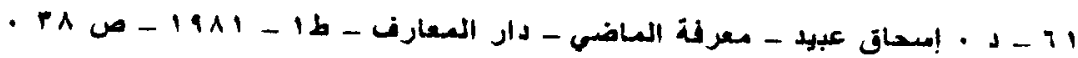

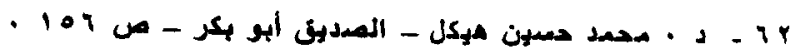

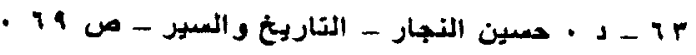

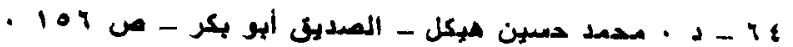

$$
\text { - Y }
$$

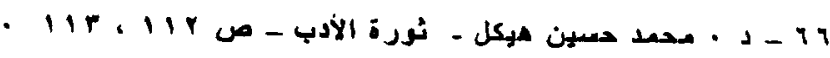

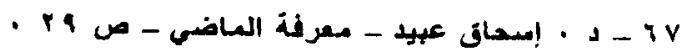

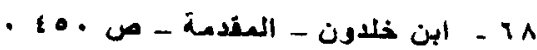

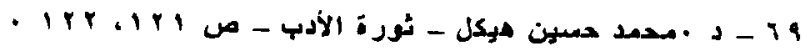

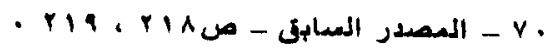

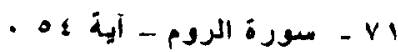

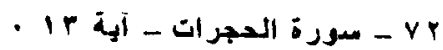

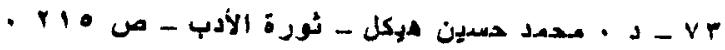

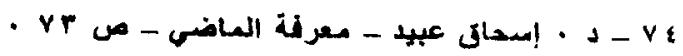

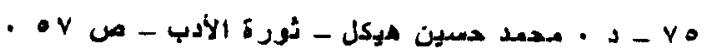


- i

- VV

. I V ص - VA

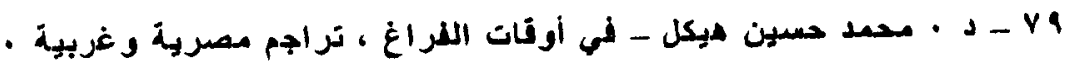

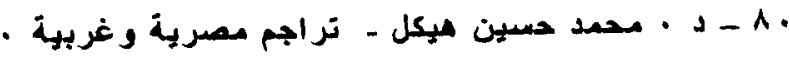

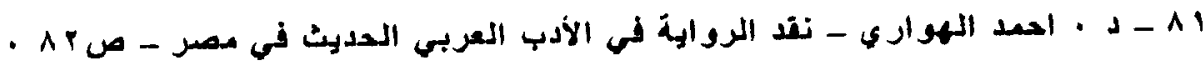

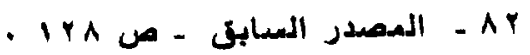

.

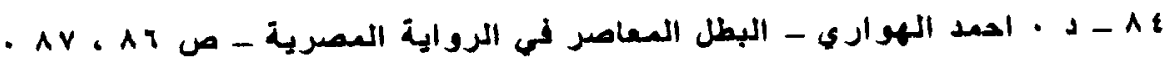

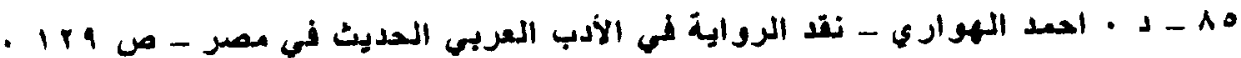

- 1 
